\title{
Feeding interventions for growth and development in infants with cleft lip, cleft palate or cleft lip and palate (Review)
}

Bessell A, Hooper L, Shaw WC, Reilly S, Reid J, Glenny AM

Bessell A, Hooper L, Shaw WC, Reilly S, Reid J, Glenny AM.

Feeding interventions for growth and development in infants with cleft lip, cleft palate or cleft lip and palate.

Cochrane Database of Systematic Reviews 2011, Issue 2. Art. No.: CD003315.

DOI: 10.1002/14651858.CD003315.pub3.

www.cochranelibrary.com

Feeding interventions for growth and development in infants with cleft lip, cleft palate or cleft lip and palate 
TABLE OF CONTENTS

HEADER

ABSTRACT

PLAIN LANGUAGE SUMMARY

BACKGROUND

OBJECTIVES

METHODS

Figure 1.

RESULTS

Figure 2.

Figure 3.

Figure 4.

Figure 5.

Figure 6.

DISCUSSION

AUTHORS' CONCLUSIONS

ACKNOWLEDGEMENTS

REFERENCES

CHARACTERISTICS OF STUDIES

DATA AND ANALYSES

Analysis 1.1. Comparison 1 Rigid versus squeezable bottle, Outcome 1 Weight (kg).

Analysis 1.2. Comparison 1 Rigid versus squeezable bottle, Outcome 2 Length (cm).

Analysis 1.3. Comparison 1 Rigid versus squeezable bottle, Outcome 3 Head circumference (cm).

Analysis 2.1. Comparison 2 Breastfeeding versus spoon-feeding, Outcome 1 Weight (kg).

Analysis 2.2. Comparison 2 Breastfeeding versus spoon-feeding, Outcome 2 Duration of hospital stay (days).

Analysis 3.1. Comparison 3 Maxillary plate versus no plate, Outcome 1 Weight (kg).

Analysis 3.2. Comparison 3 Maxillary plate versus no plate, Outcome 2 Length $(\mathrm{cm})$.

Analysis 3.3. Comparison 3 Maxillary plate versus no plate, Outcome 3 Head Circumference $(\mathrm{cm})$.

APPENDICES

WHAT'S NEW

HISTORY

CONTRIBUTIONS OF AUTHORS

DECLARATIONS OF INTEREST

SOURCES OF SUPPORT

DIFFERENCES BETWEEN PROTOCOL AND REVIEW

INDEX TERMS 
[Intervention Review]

\section{Feeding interventions for growth and development in infants with cleft lip, cleft palate or cleft lip and palate}

Alyson Bessell1, Lee Hooper², William C Shaw ${ }^{3}$, Sheena Reilly4, Julie Reid5, Anne-Marie Glenny 6

1Department of Oral and Dental Sciences, University of Bristol, Bristol, UK. 2School of Medicine, Health Policy \& Practice, University of East Anglia, Norwich, UK. ${ }^{3}$ Department of Orthodontics, School of Dentistry, The University of Manchester, Manchester, UK. ${ }^{4}$ Department of Pediatrics, University of Melbourne, Melbourne, Australia. 5Speech Pathology Department, Royal Children's Hospital, Melbourne, Australia. ${ }^{6}$ Cochrane Oral Health Group, School of Dentistry, The University of Manchester, Manchester, UK

Contact address: Alyson Bessell, Department of Oral and Dental Sciences, University of Bristol, Lower Maudlin Street, Bristol, BS1 2LY, UK. alyson.bessell@bristol.ac.uk.

Editorial group: Cochrane Oral Health Group.

Publication status and date: New search for studies and content updated (no change to conclusions), published in Issue 2, 2011.

Citation: Bessell A, Hooper L, Shaw WC, Reilly S, Reid J, Glenny AM. Feeding interventions for growth and development in infants with cleft lip, cleft palate or cleft lip and palate. Cochrane Database of Systematic Reviews 2011, Issue 2. Art. No.: CD003315. DOI: 10.1002/14651858.CD003315.pub3.

Copyright @ 2011 The Cochrane Collaboration. Published by John Wiley \& Sons, Ltd.

\section{A B S T R A C T}

\section{Background}

Cleft lip and cleft palate are common birth defects, affecting about one baby of every 700 born. Feeding these babies is an immediate concern and there is evidence of delay in growth of children with a cleft as compared to those without clefting. In an effort to combat reduced weight for height, a variety of advice and devices are recommended to aid feeding of babies with clefts.

\section{Objectives}

This review aims to assess the effects of these feeding interventions in babies with cleft lip and/or palate on growth, development and parental satisfaction.

\section{Search methods}

The following electronic databases were searched: the Cochrane Oral Health Group Trials Register (to 27 October 2010), the Cochrane Central Register of Controlled Trials (CENTRAL) (The Cochrane Library 2010, Issue 4), MEDLINE via OVID (1950 to 27 October 2010), EMBASE via OVID (1980 to 27 October 2010), PsycINFO via OVID (1950 to 27 October 2010) and CINAHL via EBSCO (1980 to 27 October 2010). Attempts were made to identify both unpublished and ongoing studies. There was no restriction with regard to language of publication.

\section{Selection criteria}

Studies were included if they were randomised controlled trials (RCTs) of feeding interventions for babies born with cleft lip, cleft palate or cleft lip and palate up to the age of 6 months (from term).

\section{Data collection and analysis}

Studies were assessed for relevance independently and in duplicate. All studies meeting the inclusion criteria were data extracted and assessed for validity independently by each member of the review team. Authors were contacted for clarification or missing information whenever possible.

\section{Main results}

Five RCTs with a total of 292 babies, were included in the review. Comparisons made within the RCTs were squeezable versus rigid feeding bottles (two studies), breastfeeding versus spoon-feeding (one study) and maxillary plate versus no plate (two studies). No statistically 
significant differences were shown for any of the primary outcomes when comparing bottle types, although squeezable bottles were less likely to require modification. No difference was shown for infants fitted with a maxillary plate compared to no plate. However, there was some evidence of an effect on weight at 6 weeks post-surgery in favour of breastfeeding when compared to spoon-feeding (mean difference $0.47 ; 95 \%$ confidence interval 0.20 to 0.74 ).

\section{Authors' conclusions}

Squeezable bottles appear easier to use than rigid feeding bottles for babies born with clefts of the lip and/or palate, however, there is no evidence of a difference in growth outcomes between the bottle types. There is weak evidence that breastfeeding is better than spoonfeeding following surgery for cleft. There was no evidence to suggest that maxillary plates assist growth in babies with clefts of the palate. No evidence was found to assess the use of any types of maternal advice and/or support for these babies.

\section{PLAIN LANGUAGE SUMMARY}

\section{Feeding interventions for growth and development in infants with cleft lip, cleft palate or cleft lip and palate}

Cleft lip and cleft palate (the roof of the mouth) are common defects. The severity of the cleft (opening) varies and it can occur on one (unilateral) or both sides (bilateral). It can be difficult to feed babies enough nutritious food when they have this condition, and there is evidence of delayed development in children born with cleft.

This review aimed to compare the effects of different feeding interventions such as maternal advice and support, modified bottles and/ or teats, obturating or maxillary plates (plates placed in the roof of the mouth to artificially close the cleft palate) and supplemental breastfeeding in babies with cleft lip and/or palate prior to, or following, closure. Interventions in the first 6 months from term and used with breast milk or formula feeding only were considered, but outcomes (measures of growth, development and parental satisfaction) may have been measured at any time including adulthood.

Maternal advice and support on feeding techniques and breastfeeding positions are often provided, but no studies evaluated the effectiveness of this intervention. Squeezable rather than rigid bottles may be easier to use for feeding babies with cleft lip and/or palate, and breastfeeding may have growth advantages over spoon-feeding following cleft lip surgery. Only five studies (including 292 babies) compared the effects of feeding interventions in babies with cleft lip and/or palate on growth, development or parental satisfaction. Evidence for breastfeeding rather than spoon-feeding following surgery was weak and there was a suggestion that squeezable bottles may be more manageable than rigid ones. No evidence was found to support the use of maxillary plates in babies with unilateral clefts and no studies assessed the effects of maternal advice or support. Further research is required to assess the most effective feeding interventions to prevent developmental delays in infants with cleft lip and/or palate. 


\section{B A C K G R O U N D}

\section{Description of the Condition}

Cleft lip and cleft palate are common birth defects, between them affecting about one baby of every 700 born. The Cleft Lip and Palate Association in the UK (CLAPA 2001) define cleft lip as "an opening in the upper lip between the mouth and the nose... it can range from a slight notch in the coloured portion of the lip to complete separation in one or both sides of the lip extending up and into the nose". They explain cleft palate as occurring when "the roof of the mouth is not joined completely....[this can] range from just an opening at the back of the soft palate to a nearly complete separation of the roof of the mouth (soft and hard palate)". These two conditions may arise early in pregnancy whilst an unborn baby is developing, and may occur independently or together (in cleft lip and palate). The cleft may be on one side (unilateral) or both sides (bilateral).

A cleft lip may cause a problem in creating a seal around the nipple, but closure can still generally be obtained. However, a cleft palate prevents the baby from creating the negative pressure necessary to feed and may also lead to breathing problems during feeding. At the very least this lengthens feeding times considerably. Clefting of the hard palate also limits the normal use of the tongue to compress the nipple (Shprintzen 1995).

A number of studies have examined birthweight in children born with cleft lip and/or palate (Avedian 1980; Duncan 1983; Becker 1998). The results vary but suggest that babies with cleft lip and palate are lighter and smaller than babies without a cleft. Variation in results may be due to confounding factors such as maternal age or parity (Becker 1998) or other social factors. One study reports data by type of orofacial cleft and found that infants with an isolated cleft lip were no lighter than babies without a cleft. However, those infants born with either a cleft palate or a cleft lip and palate were found to be lighter (Becker 1998). Jensen 1983 studied Danish boys aged 6 to 20 years with clefts and compared them with a control group, finding delayed skeletal maturity in boys with clefts over the whole period. Jones 1988 found that weight gain per week was lower in neonates with clefts than without. More recently Lee 1997 found that clefting was associated with significant growth faltering in early infancy, but that children attained their expected weight and height by about 2 years of age. Clefting has also been associated with increased risks of failure to thrive (Marcovitch 1994) and severe dehydration (Livingstone 2000).

There appear to be additional developmental delays in some children with cleft lip and/or palate, which may also be linked to nutritional status early in life. Jocelyn 1996 found that children with a cleft had significantly lower scores on tests of cognition, comprehension and expressive language abilities than matched control children at 12 and 24 months. Neiman 1997 found that at 36 months toddlers with a cleft showed significantly lower developmental performance in fine motor, gross motor and expressive language skills compared with toddlers without a cleft. Maternal attachment may also be affected (Speltz 1990).

\section{Description of the Intervention}

In an effort to combat reduced weight for height, a variety of advice and devices are recommended to aid the feeding of babies born with a cleft. These include a variety of modified bottles and teats
(Clarren 1987; CLAPA 2001), measures to supplement breastfeeding (Clarren 1987; Wide Smiles 2001), obturating plates (Balluff 1986; Chen 1990; Nagda 1996; Kogo 1997) and advice or training to parents (Richard 1991; Danner 1992). An obturating plate is an acrylic appliance placed over the gums of the babies upper jaw so that the cleft between the mouth and nose is covered. They may be passive, or occasionally are used to adjust the relationship between the jaw segments. The methods suggested vary with cleft type and severity (Clarren 1987), from healthcare centre to healthcare centre (Shaw 1999), as well as preoperatively and postoperatively.

\section{Why it is important to do this review}

Feeding of the baby is an immediate concern because the lip and/ or palate are affected, and there is evidence of a delay in growth of children born with clefts as compared to those without clefting. This review aimed to assess the effects of these feeding interventions for babies with cleft lip and/or palate on growth, development and parental satisfaction. Suitable feeding interventions may help to prevent developmental delay in infants with cleft lip and/or palate.

\section{O B JECTIVES}

This review aimed to compare the effects of differing feeding interventions such as maternal advice and support, modified bottles and/or teats, obturating plates and supplemental breastfeeding in babies with cleft lip and/or palate prior to, or following, closure.

Interventions in the first 6 months from term and used with breast milk or formula feeding only were considered, but outcomes (measures of growth, development and parental satisfaction) may have been measured at any time including adulthood.

\section{METHODS}

\section{Criteria for considering studies for this review}

\section{Types of studies}

Randomised controlled trials (RCTs), using either true or quasi methods of random allocation, were included.

\section{Types of participants}

Babies born with cleft lip, cleft palate or cleft lip and palate up to the age of 6 months (from term). The babies may have been waiting for an operation to close the cleft, recovering from one, or between operations. Babies with Pierre Robin sequence or other syndromes were not included in this review.

\section{Types of interventions}

Interventions may have included modified bottles, cups, spoons, pumps, positions, techniques and/or teats (to supplemental breastfeeding or instead of breastfeeding), obturating plates or maternal advice and support (during breast or bottle feeding). Any intervention could be compared to any other or to unmodified equipment or advice.

\section{Types of outcome measures}

\section{Primary outcomes}

The primary outcome measured in this review was growth. These measures of growth may have included weight until age 16 , growth centiles to age 16 , head circumference up to 12 months and length. 


\section{Secondary outcomes}

Secondary outcomes measured may have included:

- development (e.g. standard childhood development indices, employment or marital status in adulthood);

- parental satisfaction (e.g. assessment of confidence with feeding, or that the child was getting enough feed, time taken feeding).

These secondary outcomes did not have to be included with studies to make papers eligible for inclusion.

\section{Search methods for identification of studies}

For the identification of studies included or considered for this review, detailed search strategies were developed for each database searched. These were based on the search strategy developed for MEDLINE (OVID) but revised appropriately for each database. Details of the MEDLINE search are provided in Appendix 1.

\section{Electronic searching}

The following electronic databases were searched:

- Cochrane Oral Health Group's Trials Register (to 27 October 2010) (see Appendix 2).

- Cochrane Central Register of Controlled Trials (CENTRAL) (The Cochrane Library 2010, Issue 4) (see Appendix 3).

- MEDLINE via OVID (1950 to 27 October 2010) (see Appendix 1).

- EMBASE via OVID (1980 to 27 October 2010) (see Appendix 4).

- PsycINFO via OVID (1950 to 27 October 2010) (see Appendix 5).

- CINAHL via EBSCO (1980 to 27 October 2010) (see Appendix 6).

Handsearching was undertaken as part of the Cochrane worldwide handsearching programme (see the Cochrane Master List of journals being searched for information).

Reference lists of all relevant review articles and trials identified for inclusion in the systematic review were screened to identify any additional studies. No attempt was made to contact manufacturers of specialist feeding equipment.

\section{Data collection and analysis}

\section{Selection of studies}

The titles and abstracts (when available) of all reports identified through the electronic searches were scanned independently and in duplicate. For studies appearing to meet the inclusion criteria, or for which there were insufficient data in the title and abstract to make a clear decision, the full report was obtained. The full reports obtained from all the electronic and other methods of searching were assessed independently and in duplicate to establish whether the studies met the inclusion criteria or not. Disagreements were resolved by discussion. Where resolution was not possible, it was planned that a third reviewer would be consulted. All studies meeting the inclusion criteria were assessed for validity and data extracted. Studies rejected at this or subsequent stages were recorded in the table of excluded studies, and reasons for exclusion recorded.

\section{Data extraction and management}

Data were extracted from the included studies independently and in duplicate using a specially designed data extraction form. Any disagreements between reviewers were discussed by the review team. Authors were contacted for clarification or missing information whenever possible. Data were to be excluded until further clarification was available if agreement could not be reached.

For each trial the following data were recorded.

- Date of the study, year of publication, and country of origin, funding.

- Details of the participants including demographic characteristics, source of recruitment and criteria for inclusion.

- Details on the type and duration of intervention, duration of follow-up.

- Details of the outcomes reported, including method of assessment (where measurement scales were used it was recorded whether or not they had been validated).

\section{Assessment of risk of bias in included studies}

This was conducted using the recommended approach for assessing risk of bias in studies included in Cochrane reviews (Higgins 2009). We used the two-part tool, addressing the six specific domains (namely sequence generation, allocation concealment, blinding, incomplete outcome data, selective outcome reporting and 'other issues'). Each domain includes one or more specific entries in a 'Risk of bias' table. Within each entry, the first part of the tool involves describing what was reported to have happened in the study. The second part of the tool involves assigning a judgement relating to the risk of bias for that entry. This is achieved by answering a pre-specified question about the adequacy of the study in relation to the entry, such that a judgement of 'Yes' indicates low risk of bias, 'No' indicates high risk of bias, and 'Unclear' indicates unclear or unknown risk of bias.

The domains of sequence generation, allocation concealment, blinding, incomplete outcome data, selective outcome reporting and other sources of bias are each addressed in the tool by a single entry for each study. The risk of bias assessment was undertaken independently and in duplicate by two review authors as part of the data extraction process.

After taking into account the additional information provided by the authors of the trials, studies were grouped into the following categories.

\begin{tabular}{llll}
\hline Risk of bias & Interpretation & Within a study & Across studies \\
\hline $\begin{array}{lll}\text { Low risk of } \\
\text { bias. }\end{array}$ & $\begin{array}{l}\text { Plausible bias unlikely to seriously } \\
\text { alter the results. }\end{array}$ & $\begin{array}{l}\text { Low risk of bias for all key } \\
\text { domains. }\end{array}$ & $\begin{array}{l}\text { Most information is from studies at low risk of } \\
\text { bias. }\end{array}$ \\
\hline
\end{tabular}


Unclear risk Plausible bias that raises some of bias. doubt about the results.
Unclear risk of bias for one or more key domains.
Most information is from studies at low or unclear risk of bias.
High risk of Plausible bias that seriously weakbias.
High risk of bias for one or more key domains.
The proportion of information from studies at high risk of bias is sufficient to affect the interpretation of results.

A risk of bias table was completed for each included study and results will also be presented graphically (Figure 1).

\section{Figure 1. Risk of bias graph: review authors' judgements about each risk of bias item presented as percentages across all included studies.}

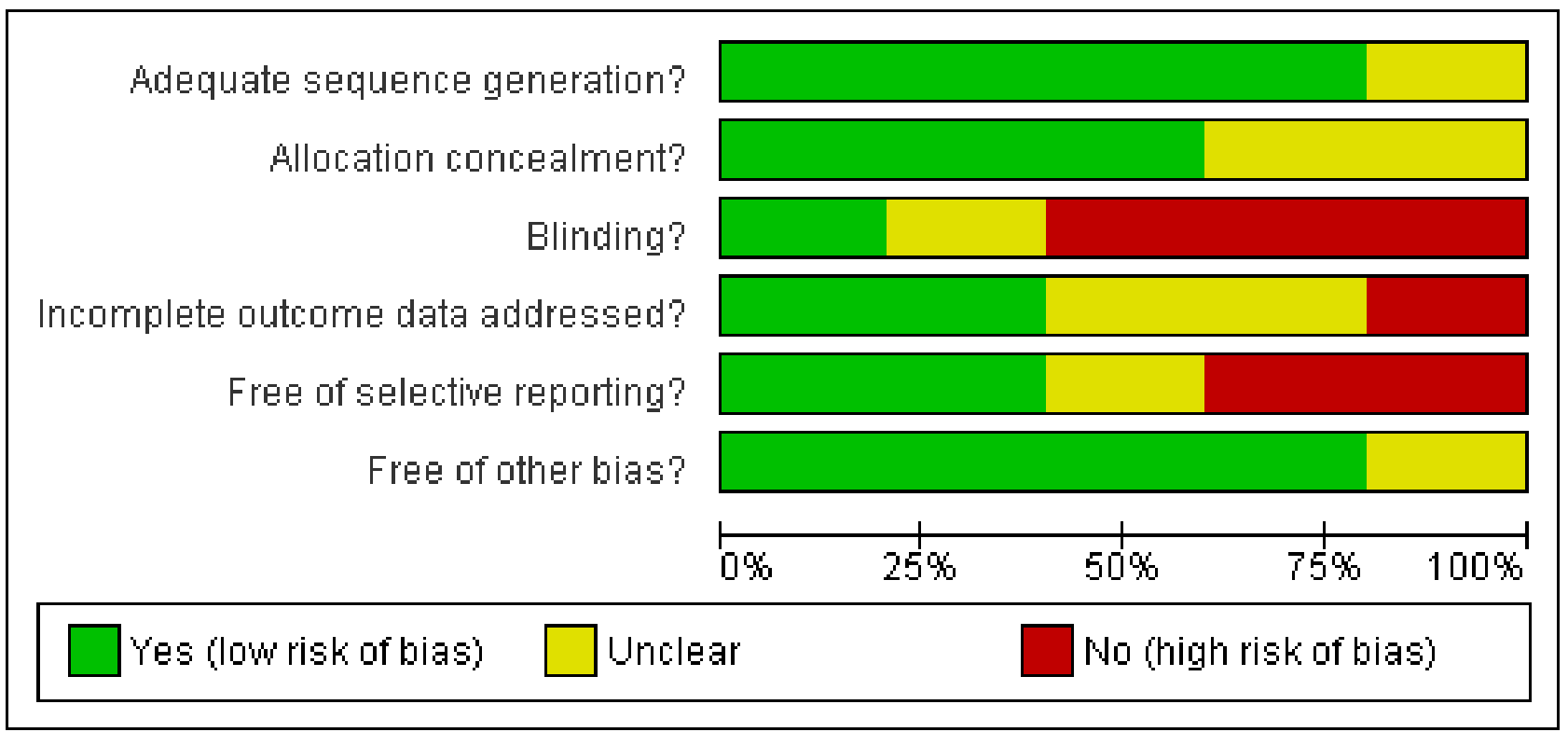

Further quality assessment was carried out to assess other potential threats to validity, including: definition of exclusion/ inclusion criteria, adequate definition of success criteria and comparability of control and treatment groups at entry. It was planned that a pilot test of the quality assessment criteria would be conducted using several articles, however, only one study was used for pilot testing due to the paucity of included trials.

\section{Measures of treatment effect}

For dichotomous outcomes, the estimate of effect of an intervention was to be expressed as risk ratios together with $95 \%$ confidence intervals. For continuous outcomes, means and standard deviations were used to summarise the data for each group.

\section{Dealing with missing data}

Where necessary the authors of the included studies were contacted to provide missing or incomplete data. Sensitivity analyses were to be undertaken to examine the effect of randomisation, allocation concealment and blind outcome assessment on the overall estimates of effect. In addition, the effect of including unpublished literature on the review's findings was also to be examined if data had allowed.

\section{Assessment of heterogeneity}

Clinical heterogeneity was assessed by examining the types of participants, interventions and outcomes in each study. Only if there were studies of similar comparisons, reporting the same outcome measures, was meta-analysis attempted. Risk ratios were to be combined for dichotomous data, and weighted mean differences for continuous data, using a random-effects model. The significance of any discrepancies in the estimates of the treatment effects from the different trials were assessed by means of Cochran's test for significant statistical heterogeneity $(P<0.1)$.

\section{Data synthesis}

Where possible meta-analyses were undertaken to compare studies with the same outcomes. These included studies assessing bottle feeding approaches, comparisons of breast and spoon feeding and the use of maxillary plates prior to surgery. A fixed-effect approach was employed.

Subgroup analyses were to be undertaken to compare: results for cleft lip only (pre- and post-closure), cleft palate only (pre- and postclosure) and cleft lip and palate. However, insufficient data were available for subgroup analyses. 


\section{RESULTS}

\section{Description of studies}

\section{Results of the search}

Search results yielded 150 possible studies. Of these 73 were not relevant for inclusion within the review. A further 69 studies were ineligible for inclusion because they were not randomised controlled trials (RCTS). This left a remaining 8 studies to assess.

\section{Included studies}

See Characteristics of included studies table.

Four single-centred RCTs (Brine 1994; Darzi 1996; Shaw 1999; Masarei 2007) and one multicentred RCT (Prahl 2005) were included in the review. The studies were carried out in the USA (Brine 1994), India (Darzi 1996), the UK (Shaw 1999; Masarei 2007) and the Netherlands (Prahl 2005).

\section{Excluded studies}

Three studies were excluded. Two studies did not contain measures of growth data. The remaining study assessed the use of bottle feeding after cleft repair on infants older than 6 months of age at baseline (see Characteristics of excluded studies table).

\section{Characteristics of participants}

The studies included babies with cleft lip only (Darzi 1996), cleft palate or cleft lip and palate (prior to closure) (Brine 1994; Masarei 2007), babies with clefts of lip, palate or lip and palate (Shaw 1999) or babies with complete unilateral cleft lip and palate (Prahl 2005). Four studies clearly stated that babies with major congenital anomalies or recognised medical conditions were excluded from the study (Brine 1994; Shaw 1999; Prahl 2005; Masarei 2007). However it must be noted that some congenital abnormalities associated with cleft that can affect growth may be difficult to detect, making accurate exclusion of participants difficult. Therefore, the age of the included babies ranged from birth (Brine 1994; Shaw 1999; Prahl 2005; Masarei 2007) up to 6 months (Darzi 1996). The number of babies included in the studies ranged from 37 (Brine 1994) to 101 (Shaw 1999).

\section{Characteristics of interventions}

Two trials compared bottle type (squeezable versus rigid) (Brine 1994; Shaw 1999), with all mothers receiving feeding advice. In the trial by Brine et al (Brine 1994) an intraoral maxillary obturator was fitted for infants with complete cleft lip and palate. Two further trials compared the use of a passive, acrylic plate designed to cover the hard palate and the alveolar segments, with no plate (Prahl 2005; Masarei 2007). The fifth study compared post-surgical breastfeeding or spoon-feeding (Darzi 1996). Follow up of the mother-infant pairs ranged from 7 to 13 months (Darzi 1996; Prahl 2005; Masarei 2007) up to 18 months (Brine 1994).

\section{Characteristics of outcomes}

All trials provided measures of weight $(\mathrm{kg})$. Head circumference and/or length were reported in four trials (Brine 1994; Shaw 1999; Prahl 2005; Masarei 2007). Brine et al also recorded tricep and subscapular skinfold measurements and mid-arm circumference (Brine 1994). Prahl et al reported mean weight-for-length, length- for-age and weight-for-age z-scores (mean weight and length data were supplied separately by the author) (Prahl 2005).

Measurements were recorded up to 12 months (Shaw 1999; Masarei 2007) and 18 months (Brine 1994; Prahl 2005) in three studies. Darzi and colleagues only presented data for 3 and 6 weeks post-surgery, despite the trial having a 7 to 13 month follow-up (Darzi 1996).

In addition to the anthropometric measurements undertaken, energy and protein intakes were recorded from food records (Brine 1994), physiological measures of feeding were reported (Prahl 2005; Masarei 2007) and parental satisfaction and reliability of feeding methods reported (Shaw 1999).

Adverse events (Darzi 1996; Shaw 1999), quality of life (Shaw 1999) and cost data (Darzi 1996) were also reported.

\section{Risk of bias in included studies}

See risk of bias tables in 'Characteristics of included studies'.

\section{Randomisation}

Four studies were coded as 'Yes' indicating low risk of bias with regard to the method used to generate the randomisation sequence (Darzi 1996; Shaw 1999; Prahl 2005; Masarei 2007). In the earlier of these studies, randomisation was undertaken using drawing of lots (Darzi 1996). In the second trial participants were initially stratified into three groups according to the extent of palatal cleft (Shaw 1999). A statistician constructed a separate randomisation list for each group using the method of randomised permuted blocks with a block size of four. A computerised balanced allocation was used to randomise babies in the third trial in order to minimise potential imbalances between groups (Prahl 2005). The fourth trial used a computerised allocation using minimisation procedure to reduce the potential differences between groups (Masarei 2007).

The fifth study (Brine 1994) was coded as 'Unclear' as insufficient data were presented in the study.

\section{Allocation concealment}

Three trials were coded as 'Yes' for allocation concealment (Shaw 1999; Prahl 2005; Masarei 2007). One study used sequentially numbered, sealed opaque envelopes (Shaw 1999) and the other two used a computer program (Prahl 2005; Masarei 2007). The two remaining studies were coded as 'Unclear' (Brine 1994; Darzi 1996).

\section{Blinding}

It was not possible for the parents of the babies included in the studies to be blind to intervention group. Only one trial used blind outcome assessment (Prahl 2005). For the remaining trials, blind outcome assessment was either 'Unclear' (Darzi 1996) or not undertaken (Brine 1994; Shaw 1999; Masarei 2007).

\section{Incomplete outcome data}

The greatest number of reported drop outs occurred in the study by Masarei et al (Masarei 2007). The study initially randomised 50 babies: 34 with unilateral cleft lip and palate and 16 with isolated cleft palate. One baby was withdrawn from the study due to medical complications. Twelve-month weight, height and head circumference data were not available for 18 babies. Five babies' data were missing from the maxillary plate group (four unilateral cleft lip and palate and one isolated cleft palate), whilst 13 withdrew 
from the control group (nine unilateral cleft lip and plate and four isolated cleft lip). Within the maxillary plate group, two babies were not using the plate daily (one due to anxiety about sleeping infant on his back, one felt the plate did not fit appropriately). Of these one family had ceased to use the plate by 3-month follow-up (sleep anxiety), whereas the other family had starting using the plate again. One other family abandoned using the plate by 3 months (did not fit appropriately) and a final mother did not bring her infant to the 3-month assessment. No information is provided on the remaining drop outs, except that only 14 out of 25 infants within the maxillary plate group wore it for the full 6 months.

In the study by Brine et al (Brine 1994), six mother/baby pairs withdrew (four transferred to another facility; one was dissatisfied with treatment assignment; one failed to keep appointment), but it is unclear which groups these drop outs had initially been allocated to. Data for these mother/baby pairs were not included in the analysis.

Shaw et al (Shaw 1999) initially randomised 101 babies. However, two babies were excluded from the study analysis due to severe developmental delay and phenylketonuria. Both babies had been randomised to be fed using a rigid bottle. Six mother/baby pairs randomised to the rigid bottle group transferred to the squeezable bottle due to difficulties in feeding. All mother/baby pairs were analysed according to the group to which they were initially allocated.

Forty babies, out of an initial 54, had sufficient recorded anthropometric measurements for evaluation in the trial by Prahl et al (Prahl 2005). Data was handled according to the intention-totreat principle, as described in their earlier 2001 paper (Prahl 2005).

There were no drop outs in the fifth study (Darzi 1996).

\section{Selective reporting}

Three of the studies reported all three appropriate outcome measures - length, weight, height and head circumference (Brine 1994; Shaw 1999; Masarei 2007). The fourth study reported both weight and length, but no head circumference (Prahl 2005). Darzi et al (Darzi 1996) did not report length or head circumference as outcome measures.

In the study by Masarei et al (Masarei 2007), the paper reports data at 3 months of age and again at 12 months. However, no height, weight or head circumference measures were reported at 6 months of age, prior to surgery.

\section{Other potential sources of bias}

All studies included in the review included an appropriate period of follow-up from initial and all had comparable baseline data on all outcome measures between intervention groups at baseline.

In the study by Masarei et al (Masarei 2007), the treatment of the maxillary plate group and the non-maxillary group differed in terms of number of orthodontic check up and number of visits to the clinic. This raises issues around the comparability of the two groups at 3 and 12-month follow-up on factors other than the wearing of a maxillary plate. There was also a problem with compliance within the maxillary plate condition, with many infants not wearing the plate for the full 6-month period of the study.

\section{Effects of interventions}

Three main comparisons were identified.

\section{Comparison 1: Squeezable versus rigid feeding bottles}

Two studies, providing data on 130 babies at follow-up, compared bottle types (Brine 1994; Shaw 1999). Both studies reported weight $(\mathrm{kg})$, length $(\mathrm{cm})$ and head circumference $(\mathrm{cm})$ (data presented in graph form only for Brine 1994). The larger and higher quality of the two studies provided evidence of a statistically significant benefit to head circumference at greater than 6 months (Shaw 1999). However, pooled analysis showed no difference between the two bottle types for weight (Analysis 1.1; Figure 2), height (Analysis 1.2; Figure 3) or head circumference (Analysis 1.3; Figure 4) at any time point. 
Figure 2. Forest plot of comparison: 1 Rigid versus squeezable bottle, outcome: 1.1 Weight (kg).

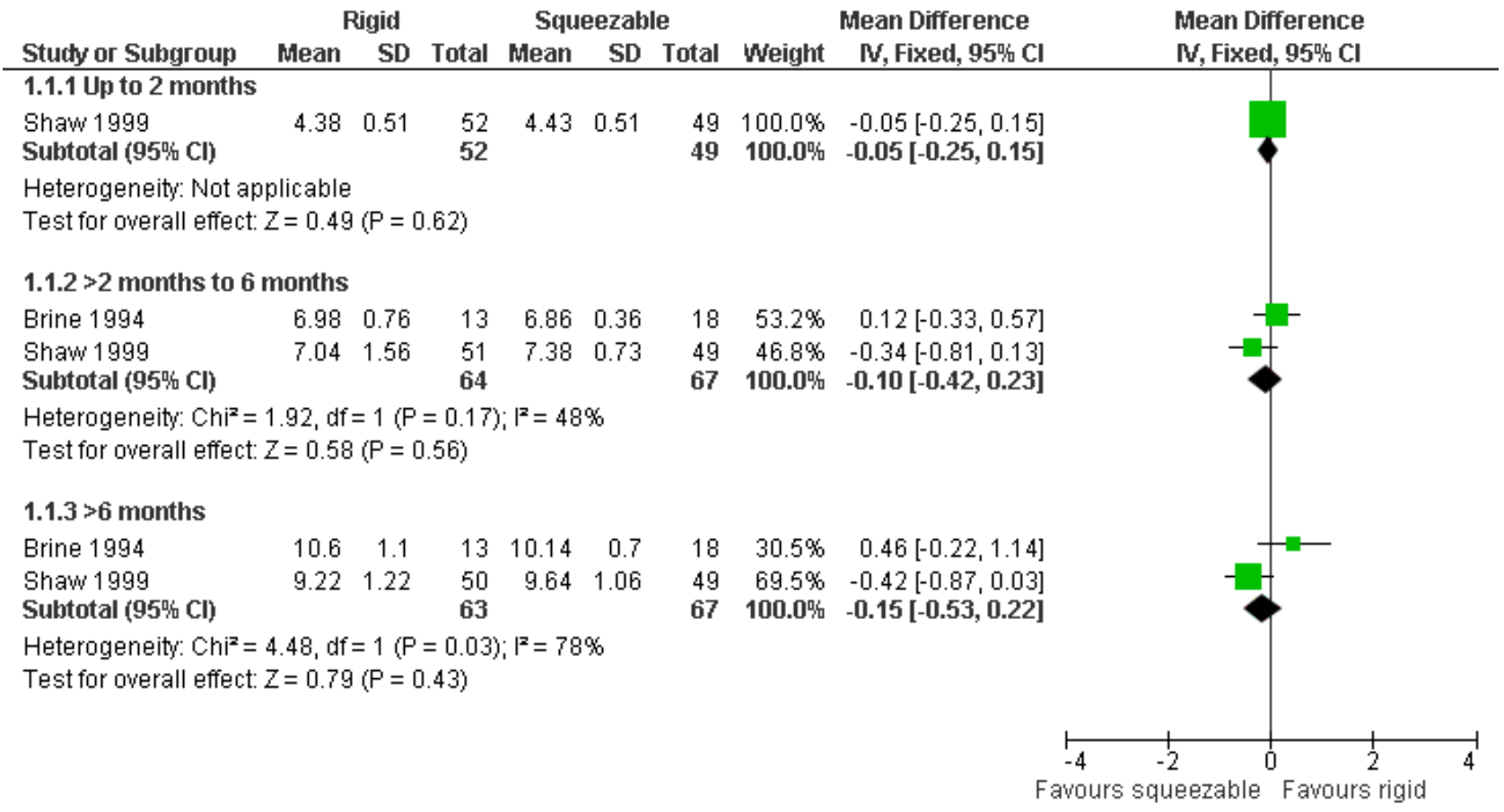

Figure 3. Forest plot of comparison: 1 Rigid versus squeezable bottle, outcome: 1.2 Length (cm).

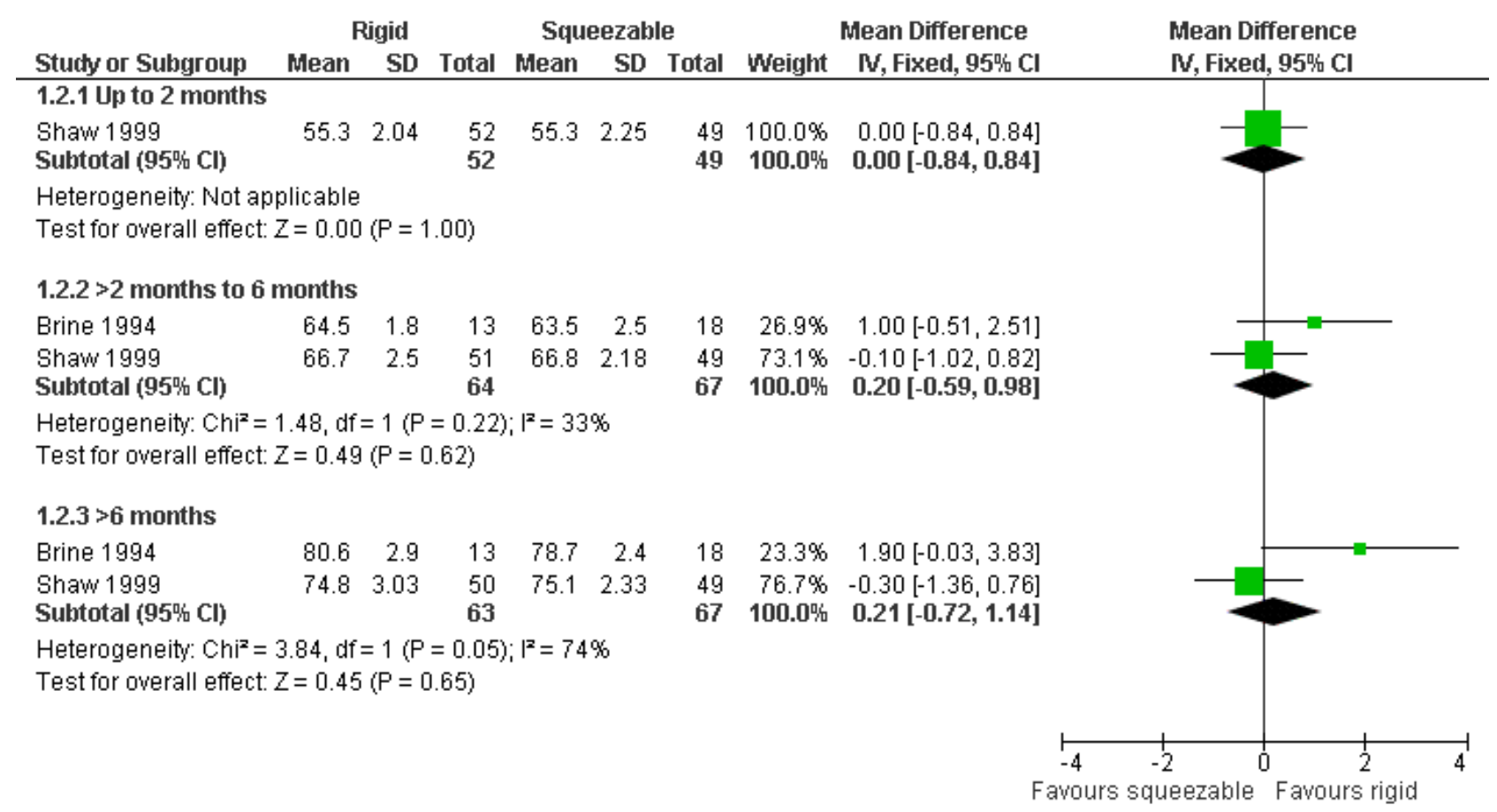


Figure 4. Forest plot of comparison: 1 Rigid versus squeezable bottle, outcome: 1.3 Head circumference (cm).

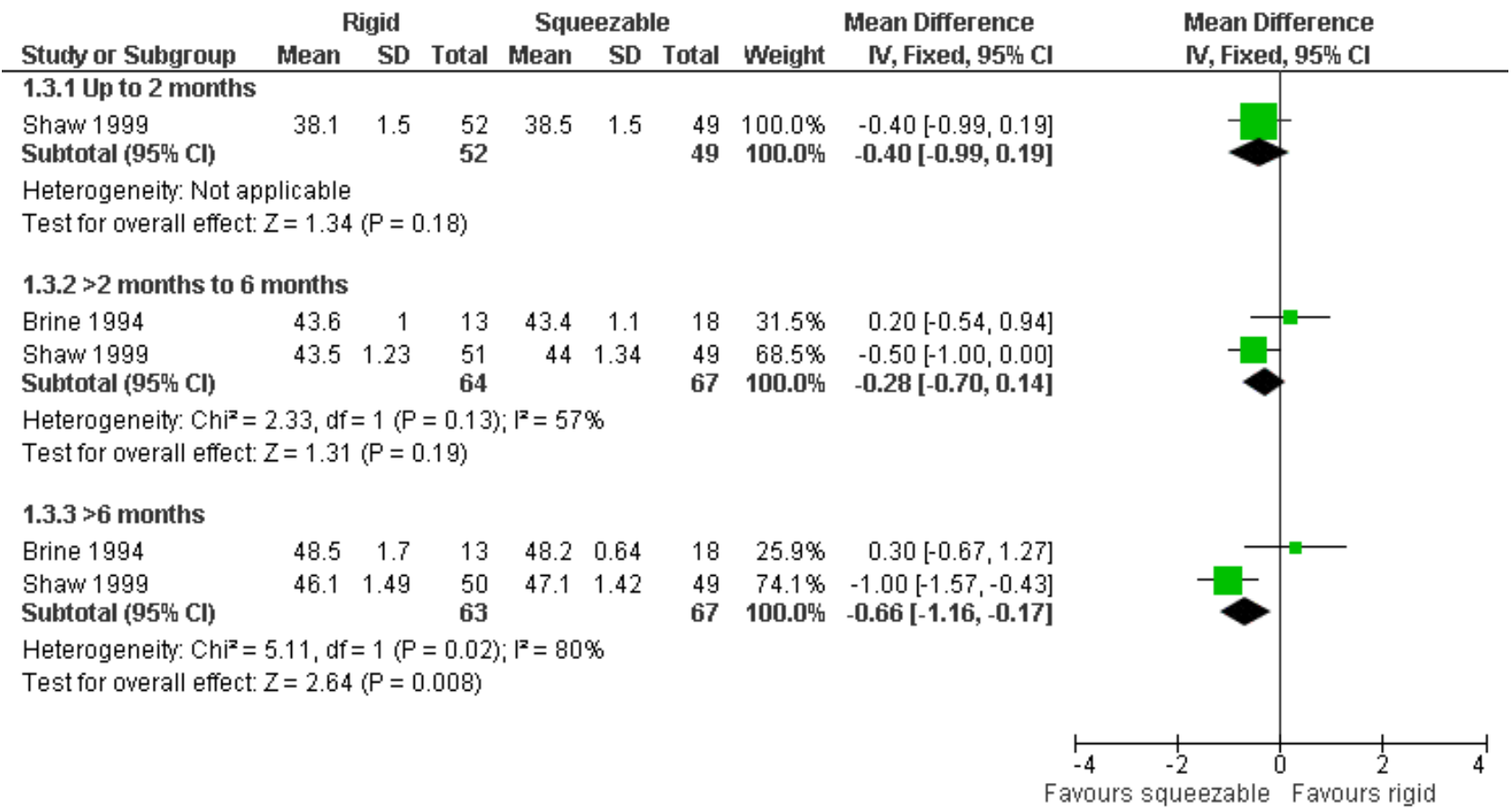

Quality of life and adverse events were reported in the study by Shaw et al (Shaw 1999) in terms of crying, feeding, sleeping and playing time, measured using a 24-hour parental log. No statistically significant differences between bottle type were shown for any of these outcomes. The number of times a bottle had to be modified by the health visitor (by increasing the number of holes in the teat, for example) was $25 / 52(48 \%)$ for the rigid bottles compared to $4 / 49(8 \%)$ for the squeezable bottles (Shaw 1999) $(P<0.05)$. Six babies randomised to the rigid bottle were transferred to the squeezable bottle due to difficulties in feeding, despite modifications to the original bottle.

Brine et al (Brine 1994) also reported mean energy and protein intakes. A difference was shown for protein intakes at 3 and 6 months, in favour of the squeezable bottle $(P<0.05)$. However, this may have been due to four infants in this group receiving a high protein soy-based formula rather than the standard formula.

\section{Comparison 2: Breastfeeding versus spoon-feeding}

One study, providing data on 40 babies, compared the effectiveness of breastfeeding babies with cleft lips, post-surgery, with spoonfeeding (Darzi 1996). A difference was shown in terms of weight $(\mathrm{kg})$ at 6-weeks post-surgery, in favour of breastfeeding (Analysis 2.1), mean difference 0.47 ( $95 \%$ confidence interval $(\mathrm{Cl}) 0.20$ to 0.74 ). The age at the time of surgery ranged between 3 to 6 months, with a mean age of 4.35 months for the breast-fed group and 4.5 months for the spoon-fed group. With regard to duration of hospital stay, no statistically significant difference was seen between the two groups.

It was noted within the study that spoon-fed infants required analgesia/sedation and intravenous fluids more often and for longer periods than breast-fed infants, although data for this were not provided. Adverse events reported were one wound dehiscence and one hypertrophy of the lip scar. Both events occurred in babies being spoon-fed.

The average total cost of hospitalisation was 98 Indian rupees in the breast-fed group and 156 Indian rupees in the spoon-fed group (Analysis 2.2). The increase in cost was due to the additional analgesia/sedation and the cost of commercial feeds.

\section{Comparison 3: Maxillary plate versus no maxillary plate}

Two studies, providing data on 26 babies at follow-up, compared the effectiveness of a passive maxillary plate, worn 24 hours a day until surgical closure of soft palate, to no plate (Prahl 2005; Masarei 2007).

The trials reported weight-for-length, length-for-age and weightfor-age z-scores, which enable data from all babies, at all follow-up appointments, to be taken into account. No statistically significant differences in the scores obtained from each group were shown. However, the authors of the Prahl 2005 study reported that the mean z-scores of the children included in the trial did differ significantly from the reference population used to calculate the scores, with the infants with a unilateral cleft being lighter and shorter throughout their first year of life.

The z-scores presented in these papers have not been displayed graphically in this review in order to make the results from the included trials more comparable. However, it is acknowledged that the presentation of z-scores is preferable when expressing child growth status (Gorstein 1994). Mean weight and length at different time points ( 2 months (54 to 67 days), 6 months (169 to 197 days), 12 months ( 235 to 379 days)) were calculated based on raw data provided by the authors. The numbers of babies included in the analyses were low as we analysed babies coming for follow-up at specific ages, but many babies did not have follow-up at these times points. A statistically significant difference in weight (Analysis 
3.1; Figure 5), in favour of the plate, was seen at 6 months (169 to 187 days) in only 28 of the babies, however, this difference was not observed at any other time point. No statistically significant differences were observed between groups with regard to length (Analysis 3.2; Figure 6) or head circumference (Analysis 3.3).

Figure 5. Forest plot of comparison: 3 Maxillary plate versus no plate, outcome: 3.1 Weight (kg).

\begin{tabular}{|c|c|c|c|c|c|c|c|c|c|}
\hline \multirow[b]{2}{*}{ Stuchy or Subgroup } & \multicolumn{2}{|c|}{ Plate } & \multicolumn{4}{|c|}{ No plate } & \multicolumn{2}{|c|}{ Mean Difference } & \multirow{2}{*}{$\begin{array}{l}\text { Mean Difference } \\
\text { N, Fixed, 95\% CI }\end{array}$} \\
\hline & Mean & SD & Total & Mean & SD & Total & Weight & 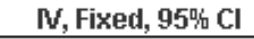 & \\
\hline \multicolumn{10}{|c|}{3.1 .12 months (54 to 67 days) } \\
\hline Masarei 2007 & 5.46 & 0.72 & 24 & 5.52 & 0.88 & 23 & $49.0 \%$ & $-0.06[-0.52,0.40]$ & \\
\hline $\begin{array}{l}\text { Prahl } 2005 \\
\text { Subtotal (95\% Cl) }\end{array}$ & 4.71 & 0.51 & $\begin{array}{l}13 \\
37\end{array}$ & 4.7 & 0.63 & $\begin{array}{l}12 \\
35\end{array}$ & $\begin{array}{r}51.0 \% \\
100.0 \%\end{array}$ & $\begin{array}{r}0.01[-0.44,0.46] \\
-0.02[-0.35,0.30]\end{array}$ & \\
\hline \multicolumn{10}{|c|}{$\begin{array}{l}\text { Heterogeneity: } \mathrm{Chi}^{2}=0.05, \mathrm{df}=1(P=0.83) ;\left.\right|^{2}=0 \% \\
\text { Test for overall effect: } Z=0.15(P=0.88)\end{array}$} \\
\hline \multicolumn{10}{|c|}{3.1 .26 months (176 to 190 days) } \\
\hline $\begin{array}{l}\text { Prahl } 2005 \\
\text { Subtotal (95\% Cl) }\end{array}$ & 7.03 & 0.53 & $\begin{array}{l}15 \\
15\end{array}$ & 7.6 & 0.92 & $\begin{array}{l}13 \\
13\end{array}$ & $\begin{array}{l}100.0 \% \\
100.0 \%\end{array}$ & $\begin{array}{l}-0.57[-1.14,-0.00] \\
-0.57[-1.14,-0.00]\end{array}$ & \\
\hline \multicolumn{10}{|c|}{$\begin{array}{l}\text { Heterogeneity: Not applicable } \\
\text { Test for overall effect: } Z=1.97(P=0.05)\end{array}$} \\
\hline \multicolumn{10}{|c|}{ 3.1.3 12 months (351 to 379 days) } \\
\hline Masarei 2007 & 10.06 & 1.42 & 20 & 10.11 & 1.47 & 12 & $36.8 \%$ & $-0.05[-1.09,0.99]$ & \\
\hline $\begin{array}{l}\text { Prahl } 2005 \\
\text { Subtotal (95\% Cl) }\end{array}$ & 9.77 & 0.85 & $\begin{array}{r}6 \\
26\end{array}$ & 9.59 & 0.72 & $\begin{array}{l}12 \\
24\end{array}$ & $\begin{array}{r}63.2 \% \\
100.0 \%\end{array}$ & $\begin{array}{r}0.18[-0.61,0.97] \\
\mathbf{0 . 1 0}[-\mathbf{0 . 5 3}, \mathbf{0 . 7 3}]\end{array}$ & \\
\hline \multicolumn{10}{|c|}{$\begin{array}{l}\text { Heterogeneity: } \mathrm{Chi}^{2}=0.12, \mathrm{df}=1(P=0.73) ;\left.\right|^{2}=0 \% \\
\text { Test for overall effect: } Z=0.30(P=0.77)\end{array}$} \\
\hline
\end{tabular}


Figure 6. Forest plot of comparison: 3 Maxillary plate versus no plate, outcome: 3.2 Length $(\mathrm{cm})$.

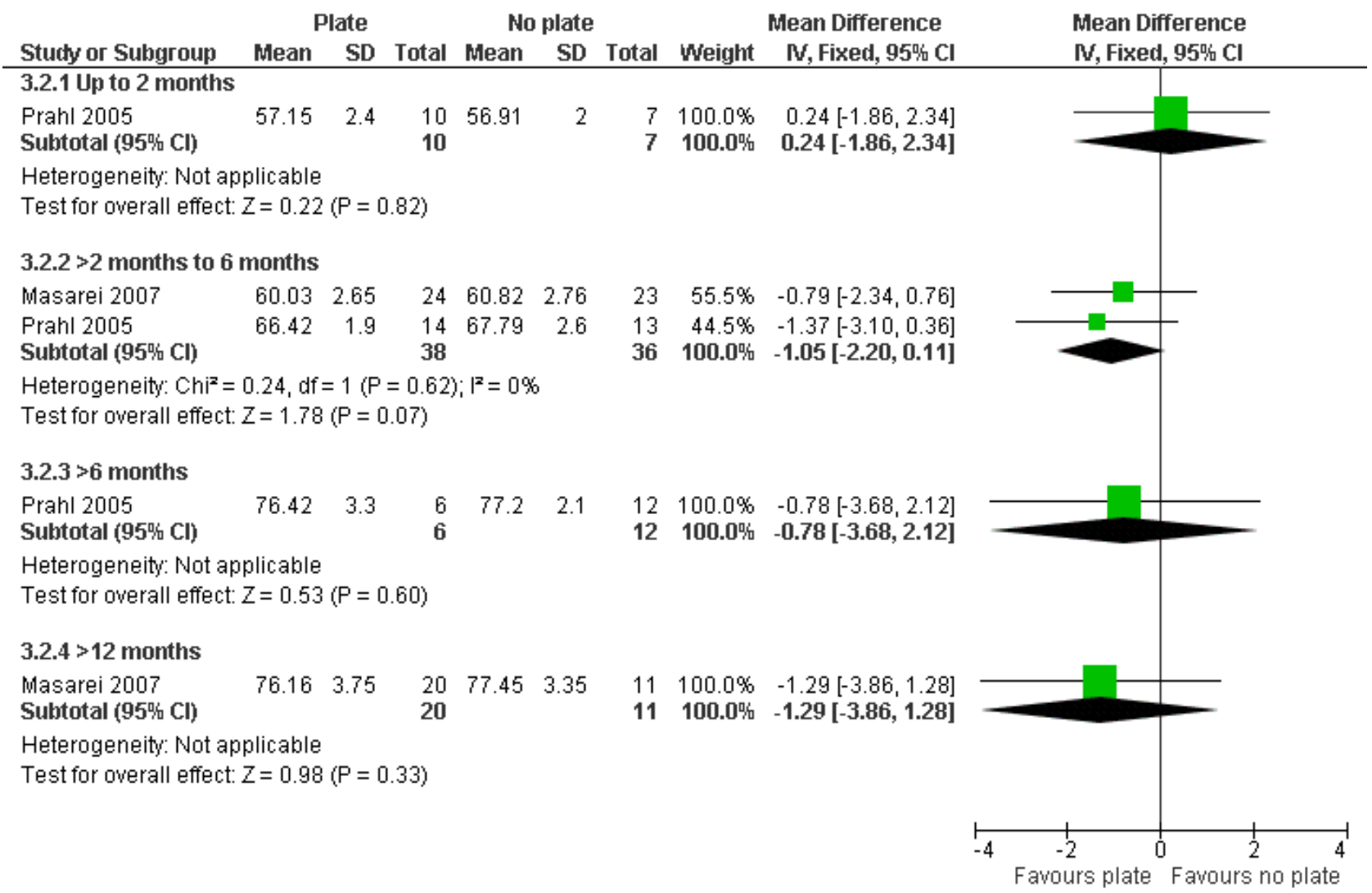

\section{DISCUSSION}

\section{Summary of main results}

This review found some evidence that breastfeeding, when compared to spoon-feeding, may improve weight gain in babies following surgery for cleft lip. However, it should be noted that the outcome measurements were only reported for up to 6 weeks post-surgery. The study was clearly randomised and all babies were followed to 6 weeks, but allocation concealment and blinding of the outcome assessor were unclear, so the results may have been biased.

No trials were identified that examined the effect of additional maternal support or advice during breastfeeding (or bottlefeeding). The World Health Organization (WHO 2001) recommends exclusive breastfeeding for 6 months, however, rates of breastfeeding babies with cleft lip and/or palate are low (Trenouth 1996). Given the recognised health benefits of breast milk mothers should not be discouraged from breastfeeding, although they should be made aware of the potential difficulties and be provided with adequate support. If direct breastfeeding is not possible, mothers may wish to feed their baby with expressed breast milk. Further studies of the most appropriate support and advice for mothers wishing to feed their baby with breast milk are required.

Although there is no consistent evidence to support or refute the use of squeezable feeding bottles over rigid feeding bottles for growth or development outcomes, the unreliability of a bottle type (determined by the number of times a bottle needed to be modified by the health visitor) was significantly greater for the rigid bottles. The squeezable bottles may not enhance (or impair) growth and development, but may be easier to use for the feeding of babies born with cleft conditions. There was no evidence to suggest that the use of maxillary plates improved growth outcomes.

\section{Overall completeness and applicability of evidence}

Feeding infants with cleft conditions is of immediate concern to both the clinician and parent in the newborn period (Young 2001). Despite this, there is little research evidence with regard to the most effective feeding intervention for such babies on growth, development and parental satisfaction. Surveys of parents of children born with a cleft lip and/or palate report some dissatisfaction with the level of care and information they receive regarding feeding, both in hospital and on discharge (Trenouth 1996; Oliver 1997).

The lack of information provided to the parents may reflect the lack of data currently available describing the nature of the problem of feeding newborn babies with a cleft lip and/or palate. Only two studies (Choi 1991; Kogo 1997) have measured intraoral negative pressure, which is thought to be absent or at least partially diminished when a cleft palate occurs. Other studies have alluded to altered tongue positions during swallowing (Campo-Paysaa 1987) and altered oro-pharyngeal stages of swallowing (Masarei 2007). Most papers simply comment on behavioural sequelae such as coughing, choking, gagging, nasal regurgitation, etc (Styer 1981; Jones 1982; Clarren 1987; Carlisle 1998). 
In addition, accurate prevalence figures for feeding problems are difficult to obtain from the literature because there has been no prospective, longitudinal population study of the extent of the problem. We do know that Jones (Jones 1982) found that $25 \%$ of a cohort of non-syndromic infants with cleft lip, cleft palate and combined cleft lip and palate had poor feeding, and Spriesterbach (Spriestersbach 1973) reported that $73 \%$ of infants with cleft palate had feeding problems. Epidemiological studies which can yield information about the basis and nature of feeding problems, prevalence and also risk factors (cleft type, cleft size, comorbidity, maternal education, socio-economic status, etc) may be beneficial.

Intervention techniques have arisen without a sound foundation. For example, we do not yet fully understand:

(a) how the structural anomaly affects the mechanics and function of sucking;

(b) how and why some infants are able to compensate/alter their sucking patterns and obtain sufficient nutrients;

(c) whether there are long term effects on feeding even after cleft repair, or whether feeding returns to normal (the belief that everything returns to normal ignores the significant motor learning that has taken place regarding sucking and swallowing over many months).

\section{Quality of the evidence}

The majority of the research literature on feeding interventions is based on uncontrolled studies, expert opinion, or nonsystematic review articles. To date, only five randomised controlled trials (RCTs) have been published which investigate feeding interventions for newborns and infants under 6 months with cleft conditions (Brine 1994; Darzi 1996; Shaw 1999; Prahl 2005; Masarei 2007). Methodological quality of these trials was variable, with no single trial meeting all six of the main quality criteria examined (randomisation, allocation concealment, blind outcome assessment, completeness of follow-up/intention-totreat analysis, free of selective outcome reporting, free of other sources of bias).

Anthropometry is widely used to monitor infant growth and to estimate child nutritional status. Gorstein et al (Gorstein 1994) have described the three most frequently used indices as weight-forheight, height-for-age and weight-for-age, with the latter being the least preferred of the three indices. Weight-for-height is perhaps the most useful of the indices for several reasons: it is sensitive to weight change over a short time period, it is useful in identifying wasted children, and it can be used in populations where age is unknown or inaccurate. The only advantage of height-for-age over weight-for-height is for the identification of stunted children. Increasingly, child growth status, in terms of the indices mentioned, is being expressed as z-scores or sd-scores (Cole 1990), providing a summary of how a child's or population's measurements relate to a suitable reference population (WHO 1986). A key advantage of the z-score is that values from a study population are likely to be normally distributed. Only two of the included RCTs presented data in this manner (Prahl 2005; Masarei 2007). The z-scores presented in the papers have not been displayed graphically in this review in order to make the results from the included trials more comparable. However, it is recommended that future trials do present weightfor-height z-scores.

Further large, high quality RCTs, with developmental and behavioural outcomes measured well into childhood, are needed to assess the effectiveness of feeding aids and support for babies with clefts of the lip, palate or lip and palate. This would allow for more conclusive findings than those presented within this systematic review due to the methodological inconsistencies of the included studies. In particular squeezable feeding bottles appear promising and should be further assessed. Multicentre studies may be useful in ascertaining larger numbers of participants, reducing the heterogeneity of the sample and providing adequate power for the investigation. Intervention studies which provide adequate data for subgroup analysis, comparing outcomes for cleft lip, cleft palate and cleft lip and palate, would be helpful. Attention needs to be given to the indices used to present data relating to child growth. Future studies also need to consider length of follow-up and ensure all studies follow infant growth at least to the age of 2 years of age to adequately control for other factors that may influence growth such as anaesthesia, illness and surgery.

\section{Potential biases in the review process}

This review attempted to provide a comprehensive assessment of multiple feeding interventions for infants with cleft lip and/or palate. The methods employed to identify studies allowed for a wide range of papers to be identified and included. However, the methodological quality of the included studies made it difficult to accurately compare studies of similar quality and with similar populations. Cleft lip, cleft palate and cleft lip and palate are three different cleft sub-phenotypes that might have a significant effect in terms of outcomes. However the included papers often did not provide enough information about the proportions of each subphenotype, or contain sufficient numbers of each to allow separate analysis of these groups.

Although the authors of this review attempted to pool the data in such a way to allow for small variations in data collection processes within each study, this is a possible area of bias. Measurements across the studies were not always collected in consistent ways, and the timings of measurements varied making it difficult to pool the data across multiple studies in a meaningful way.

It must also be noted that although many of the studies within the review highlighted that infants with known chromosomal abnormalities were excluded, this is always easy to assess. Particularly in the case of isolated cleft palate chromosomal abnormalities are common and it is often difficult to identify these micro-deletions that can be associated with developmental delay and impact on growth.

The follow-up periods of the included studies were not of sufficient length to allow for variations in growth that may be caused by confounding factors such as the impact of surgery, anaesthesia and other illnesses. Follow-up to the end of the second year of life would allow a more accurate assessment of effectiveness of the included interventions.

\section{AUTHORS' CONCLUSIONS}

\section{Implications for practice}

Squeezable bottles appear easier to use than rigid feeding bottles for babies born with clefts of the lip and/or palate, however, there is no evidence of a difference in growth outcomes between the bottle types. 
No evidence was found to assess the use of any types of maternal advice and/or support for these babies.

There is weak evidence that breastfeeding should be used in preference to spoon-feeding for babies following surgery for a cleft lip. This study requires further investigation in studies with larger sample sizes.

No evidence was found to assess types of maternal advice and/or support for these babies.

No evidence was found to support the use of maxillary plates to aid growth in these babies.

\section{Implications for research}

Further large, high quality randomised controlled trials, with developmental and behavioural outcomes measured well into childhood, are needed to assess the effectiveness of feeding aids and support for babies with clefts of the lip, palate or lip and palate. This would allow for more conclusive findings than those presented within this systematic review due to the methodological inconsistencies of the included studies. In particular squeezable feeding bottles appear promising and should be further assessed. Multicentre studies may be useful in ascertaining larger numbers of participants, reducing the heterogeneity of the sample and providing adequate power for the investigation. Intervention studies which provide adequate data for subgroup analysis, comparing outcomes for cleft lip, cleft palate and cleft lip and palate, would be helpful. Attention needs to be given to the indices used to present data relating to child growth. Future studies also need to consider length of follow-up and ensure all studies follow infant growth at least to the age of 2 years of age to adequately control for other factors that may influence growth such as anaesthesia, illness and surgery.

\section{A C K N O WLEDGEMENTS}

The review team would like to thank Sylvia Bickley for her assistance with developing the search strategies for the electronic databases and for co-ordinating handsearching for the previous version of this review. Anne Littlewood, Trials Search Co-ordinator for the Cochrane Oral Health Group, performed the electronic searching for this update. We are grateful to Liz Asbridge for the handsearching she undertook. Many thanks to Professor KuijpersJagtman and colleagues, and Dr Debbie Sell and colleagues for providing the raw data for their trial (Prahl 2005; Masarei 2007). We would also like to thank all those who provided comments on either the protocol or the review. Their comments were extremely helpful.

This publication presents independent research commissioned by the National Institute for Health Research (NIHR) under its Programme Grants for Applied Research scheme (RPPG-0707-10034). The views expressed in this publication are those of the author(s) and not necessarily those of the NHS, the NIHR or the Department of Health. 


\section{R E F E R E N C E S}

\section{References to studies included in this review}

Brine 1994 \{published data only\}

Brine EA, Rickard KA, Brady MS, Liechty EA, Manatunga A, Sadove M, et al. Effectiveness of two feeding methods in improving energy intake and growth of infants with cleft palate: a randomized study. Journal of the American Dietetic Association 1994;94(7):732-8.

\section{Darzi 1996 \{published data only\}}

Darzi MA, Chowdri NA, Bhat AN. Breast feeding or spoon feeding after cleft lip repair: a prospective, randomised study. British Journal of Plastic Surgery 1996;49(1):24-6.

Masarei 2007 \{published data only (unpublished sought but not used)\}

Masarei AG, Sell D, Habel A, Mars M, Sommerlad BC, Wade A. The nature of feeding in infants with unrepaired cleft lip and/ or palate compared with healthy noncleft infants. Cleft PalateCraniofacial Journal 2007;44(3):321-8.

Masarei, AG, Wade A, Mars M, Sommerlad BC, Sell D. A randomized control trial investigating the effect of presurgical orthopedics on feeding in infants with cleft lip and/or palate. Cleft Palate-Craniofacial Journal 2007;44(2):182-93.

\section{Prahl 2005 \{published and unpublished data\}}

Prahl C, Kuijpers-Jagtman AM, van't Hof MA, Prahl-Andersen B. $A$ randomised prospective clinical trial into the effect of infant orthopaedics on maxillary arch dimensions in unilateral cleft lip and palate (Dutchcleft). European Journal of Oral Sciences 2001;109(5):297-305.

* Prahl C, Kuijpers-Jagtman AM, van't Hof MA, PrahlAndersen B. Infant orthopedics in UCLP: effect on feeding, weight and length: a randomized clinical trial (Dutchcleft). Cleft Palate-Craniofacial Journal 2005;42(2):171-7.

Severens JL, Prahl C, Kuijpers-Jagtman AM, Prahl-Andersen B. Short-term cost-effectiveness analysis of presurgical orthopedic treatment in children with complete unilateral cleft lip and palate. Cleft Palate-Craniofacial Journal 1998;35(3):222-6.

\section{Shaw 1999 \{published data only\}}

Shaw WC, Bannister RP, Roberts CT. Assisted feeding is more reliable for infants with clefts - a randomized trial. Cleft PalateCraniofacial Journal 1999;36(3):262-8.

\section{References to studies excluded from this review}

\section{Bongaarts 2009 \{published data only\}}

Bongaarts CA, Prahl-Andersen B, Bronkhorst EM, Prahl C, Ongkosuwito EM, Borstlap WA, et al. Infant orthopedics and facial growth in complete unilateral cleft lip and palate until six years of age (Dutchcleft). Cleft palate-Craniofacial Journal 2009;46(6):654-63.
Kim 2009 \{published data only\}

Kim EK, Lee TJ, Chae SW. Effect of unrestricted bottle-feeding on early postoperative course after cleft palate repair. Journal of Craniofacial Surgery 2009;20 Suppl 2:1886-8.

Lauer 2000 \{published data only\}

Lauer G, Schimming R, Otten JE, Scmelzeisen R. Postoperative feeding strategies for infants with cleft surgery - A randomised study. [Abstract XVth Congress of the European Association for Cranio-Maxillofacial Surgery, 5-9 Sept 2000, Edinburgh, UK]. Journal of Cranio-Maxillofacial Surgery 2000;28:185-6.

\section{Additional references}

\section{Avedian 1980}

Avedian LV, Ruberg RL. Impaired weight gain in cleft palate infants. Cleft Palate Journal 1980;17(1):24-6.

\section{Balluff 1986}

Balluff MA. Nutritional needs of an infant or child with a cleft lip or palate. Ear, Nose, and Throat Journal 1986;65(7):311-5.

\section{Becker 1998}

Becker M, Svensson H, Källén B. Birth weight, body length, and cranial circumference in newborns with cleft lip and palate. Cleft Palate-Craniofacial Journal 1998;35(3):255-61.

\section{Campo-Paysaa 1987}

Campo-Paysaa A. [Treatment of labio-palate clefts]. [French]. Pediatrie 1987;42(9):697-703.

\section{Carlisle 1998}

Carlisle D. Feeding babies with cleft lip and palate. Nursing Times 1998;94(4):59-60.

\section{Chen 1990}

Chen HJ, Wang CH, Wang CC, Shieh TY. [A modified technique of obturator fabrication for cleft palate infants]. [Chinese]. Gaoxiong Yi Xue Ke Xue Za Zhi [Kaohsiung Journal of Medical Sciences] 1990;6(10):546-50.

\section{Choi 1991}

Choi BH, Kleinheinz J, Joos U, Komposch G. Sucking efficiency of early orthopaedic plate and teats in infants with cleft lip and palate. International Journal or Oral and Maxillofacial Surgery 1991;20(3):167-9.

\section{CLAPA 2001}

Cleft Lip and Palate Association. Questions and answers. CLAPA website (www.clapa.com) 2001.

\section{Clarren 1987}

Clarren SK, Anderson B, Wolf LS. Feeding infants with cleft lip, cleft palate, or cleft lip and palate. Cleft Palate Journal $1987 ; 24(3): 244-9$ 


\section{Cole 1990}

Cole TJ. The LMS method of constructing normalized growth standards. European Journal of Clinical Nutrition 1990;44(1):45-60.

\section{Danner 1992}

Danner SC. Breastfeeding the infant with a cleft defect. NAACOGS Clinical Issues in Perinatal and Womens Health Nursing 1992;3(4):634-9.

\section{Duncan 1983}

Duncan PA, Shapiro LR, Soley RL, Turet SE. Linear growth patterns in patients with cleft lip or palate or both. American Journal of Diseases in Childhood 1983;137(2):159-63.

\section{Gorstein 1994}

Gorstein J, Sullivan K, Yip R, de Onis M, Trowbridge F, Fajans P, et al. Issues in the assessment of nutritional status using anthropometry. Bulletin of the World Health Organization 1994;72(2):273-83.

\section{Higgins 2009}

Higgins JPT, Green S (editors). Cochrane handbook for systematic reviews of interventions Version 5.0.2 [updated September 2009]. The Cochrane Collaboration, 2009. Available from www.cochrane-handbook.org.

\section{Jensen 1983}

Jensen BL, Dahl E, Kreiborg S. Longitudinal study of body height, radius length and skeletal maturity in Danish boys with cleft lip and palate. Scandinavian Journal of Dental Research 1983;91(6):473-81.

\section{Jocelyn 1996}

Jocelyn LJ, Penko MA, Rode HL. Cognition, communication and hearing in young children with cleft lip and palate and in control children: a longitudinal study. Pediatrics 1996;97(4):529-34.

\section{Jones 1982}

Jones JE, Henderson L, Avery DR. Use of a feeding obturator for infants with severe cleft lip and palate. Specialist Care in Dentistry 1982;2(3):116-20.

\section{Jones 1988}

Jones WB. Weight gain and feeding in the neonate with cleft: a three-center study. Cleft Palate Journal 1988;25(4):379-84.

\section{Kogo 1997}

Kogo M, Okada G, Ishii S, Shikata M, lida S, Matsuya T. Breast feeding for cleft lip and palate patients, using the Hotz-type plate. Cleft Palate-Craniofacial Journal 1997;34(4):351-3.

\section{Lee 1997}

Lee J, Nunn J, Wright C. Height and weight achievement in cleft lip and palate. Archives of Disease in Childhood 1997;76(1):70-2

\section{Livingstone 2000}

Livingstone VH, Willis CE, Abdel-Wareth LO, Thiessen P, Lockitch $\mathrm{G}$. Neonatal hypernatremic dehydration associated with breast-feeding malnutrition: a retrospective survey. Canadian Medical Association Journal 2000;162(5):647-52.

\section{Marcovitch 1994}

Marcovitch H. Failure to thrive. BMJ 1994;308(6920):35-8.

\section{Nagda 1996}

Nagda S, Deshpande DS, Mhatre SW. Infant palatal obturator. Journal of the Indian Society of Pedodontics \& Preventive Dentistry 1996;14(1):24-5.

\section{Neiman 1997}

Neiman GS, Savage HE. Development of infants and toddlers with clefts from birth to three years of age. Cleft PalateCraniofacial Journal 1997;34(3):218-5.

\section{Oliver 1997}

Oliver RG, Jones G. Neonatal feeding of infants born with cleft lip and/or palate: parental perceptions of their experience in south Wales. Cleft Palate-Craniofacial Journal $1997 ; 34(6): 526-32$

\section{Richard 1991}

Richard ME. Feeding the newborn with cleft lip and/or palate: the enlargement, stimulate, swallow, rest (ESSR) method. Journal of Pediatric Nursing 1991;6(5):317-21.

\section{Severens 1998}

Severens JL, Prahl C, Kuijpers-Jagtman AM, Prahl-Andersen B. Short-term cost-effectiveness analysis of presurgical orthopedic treatment in children with complete unilateral cleft lip and palate. Cleft Palate-Craniofacial Journal 1998;35(3):222-6.

\section{Shprintzen 1995}

Shprintzen RJ, Bardach J. Cleft Palate Speech Management: a multidisciplinary approach. First Edition. St. Louis: Mosby, 1995. [ISBN 0-8016-6447-0]

\section{Speltz 1990}

Speltz ML, Armsden GC, Clarren SS. Effects of craniofacial birth defects on maternal functioning post-infancy. Journal of Pediatric Psychology 1990;15(2):177-96.

\section{Spriestersbach 1973}

Spriestersbach DC, Dickson DR, Fraser FC, Horowitz SL, McWilliams BJ, Paradise JL, et al. Clinical research in cleft lip and cleft palate: the state of the art. Cleft Palate Journal 1973;10:113-65.

\section{Styer 1981}

Styer GW, Freeh K. Feeding infants with cleft lip and/or palate. Journal of Obstetric, Gynecologic, and Neonatal Nursing 1981;10(5):329-32.

\section{Trenouth 1996}

Trenouth MJ, Campbell AN. Questionnaire evaluation of feeding methods for cleft lip and palate neonates. International Journal of Paediatric Dentistry 1996;6(4):241-4.

\section{WHO 1986}

WHO Working Group. Use and interpretation of anthropometric indicators of nutritional status. Bulletin of the World Health Organization 1986;64(6):929-41. 


\section{WHO 2001}

Kramer MS, Kakuma R. The optimal duration of excessive breast feeding. A systematic review. World Health Organization, 2001.

\section{Wide Smiles 2001}

Wide Smiles. Breastfeeding the cleft-affected newborn and special considerations of the bottle-fed baby with a cleft. Wide Smiles web site (www.widesmiles.org) 2001.

\section{CHARACTERISTICS OF STUDIES}

Characteristics of included studies [ordered by study ID]
Young 2001

Young JL, O'Riordan M, Goldstein JA, Robin NH. What information do parents of newborns with cleft lip, palate or both want to know?. Cleft Palate-Craniofacial Journal 2001;38(1):55-8.

* Indicates the major publication for the study

\section{Brine 1994}

\begin{tabular}{ll}
\hline Methods & Single-centre RCT. \\
& 18 month follow-up. \\
& Conducted in USA.
\end{tabular}

37 babies with cleft palate or cleft lip and palate, prior to closure. Babies with malformation syndromes, recognised medical conditions or any infant associated anomalies were excluded.

Age: 0 to 64 days (median 15).

Gender (m/f): $\mathrm{Gp} 1=13 / 5, \mathrm{Gp} 2=8 / 5$.

Cleft lip and palate: $\mathrm{Gp} 1=13, \mathrm{Gp} 2=9$.

Isolated cleft palate: $\mathrm{Gp} 1=5, \mathrm{Gp} 2=4$. Both groups received feeding advice, nutritional counselling, feed equipment and feed formula. An intraoral maxillary obturator was fitted for infants with complete CL\&P. Any mother whose infant had failure to thrive (FTT) received extra counselling and concentrated formula.

Outcomes

Anthropometric data included: weight ( $\mathrm{kg}$, using calibrated scales); length $(\mathrm{cm})$, head circumference $(\mathrm{cm})$, triceps and subscapular skinfold measurements (to nearest $0.1 \mathrm{~mm}$ approx 3 seconds after application of skinfold calipers); mid-arm circumference $(\mathrm{cm})$. Measurements taken at study entry, 3, 6, 9, 12 and 18 months of age.

Weight for length and head circumference percentiles determined using NCHS data.

Energy and protein intakes calculated from food records.

All outcomes assessed by two trained paediatric dietitians.

Notes Funded by James Whitcomb Riley Hospital for Children, Indianapolis, USA.

\section{Risk of bias}

\begin{tabular}{lll}
\hline Bias & Authors' judgement & Support for judgement \\
\hline $\begin{array}{l}\text { Adequate sequence gener- } \\
\text { ation? }\end{array}$ & Unclear risk & Sequence generation not reported. \\
\hline Allocation concealment? & Unclear risk & Not reported. \\
\hline $\begin{array}{ll}\text { Blinding? } \\
\text { All outcomes }\end{array}$ & High risk & $\begin{array}{l}\text { No blinding of outcome assessor. Researchers were responsible for data as- } \\
\text { sessment. }\end{array}$ \\
\hline $\begin{array}{l}\text { Incomplete outcome data } \\
\text { addressed? }\end{array}$ & High risk & No drop outs listed. \\
All outcomes & & No reasons for attrition given. \\
\hline
\end{tabular}


Brine 1994 (Continued)

Free of selective report- Low risk Length, weight and head circumference all reported. ing?

Free of other bias? Low risk Acceptable follow-up period of 18 months.

Comparable baseline data for length, weight and head circumference.

Darzi 1996

\begin{tabular}{|c|c|}
\hline Methods & $\begin{array}{l}\text { Single-centre RCT. } \\
6 \text { week intervention, } 7 \text { to } 13 \text { month follow-up. } \\
\text { Conducted in India. }\end{array}$ \\
\hline Participants & $\begin{array}{l}40 \text { babies with cleft lip alone. Those with associated clefts of the palate and those greater than } 6 \\
\text { months of age excluded. } \\
\text { Age: } G p 1=4.35 \text { months, } G p 2=4.5 \text { months. } \\
\text { Gender }(\mathrm{m} / \mathrm{f}): \text { not stated. } \\
\text { Complete cleft lip: } G p 1=13, \mathrm{Gp} 2=12 . \\
\text { Incomplete cleft lip: } \mathrm{Gp} 1=7, \mathrm{Gp} 2=8 .\end{array}$ \\
\hline Interventions & $\begin{array}{l}\text { Gp1. Breastfeeding (postsurgical) }(n=20) \text {. } \\
\text { Gp2. Spoon-feeding (postsurgical) }(n=20) \text {. } \\
\text { All CL were repaired when child was } 3 \text { to } 6 \text { months old. }\end{array}$ \\
\hline Outcomes & $\begin{array}{l}\text { Weight (kg) recorded at } 3 \text { and } 6 \text { weeks post-surgery. } \\
\text { Adverse events and cost data also reported. }\end{array}$ \\
\hline Notes & Funding not stated. \\
\hline
\end{tabular}

\section{Risk of bias}

\begin{tabular}{|c|c|c|}
\hline Bias & Authors' judgement & Support for judgement \\
\hline $\begin{array}{l}\text { Adequate sequence gener- } \\
\text { ation? }\end{array}$ & Low risk & $\begin{array}{l}\text { Infants were allocated by asking mothers to pick a numbered slip of paper } \\
\text { from a well shuffled box containing } 40 \text { numbered slips of paper, } 20 \text { for breast } \\
\text { feeding and } 20 \text { for spoon feeding. }\end{array}$ \\
\hline Allocation concealment? & Unclear risk & Not reported. \\
\hline $\begin{array}{l}\text { Blinding? } \\
\text { All outcomes }\end{array}$ & Unclear risk & Not reported. \\
\hline $\begin{array}{l}\text { Incomplete outcome data } \\
\text { addressed? } \\
\text { All outcomes }\end{array}$ & Low risk & No drop outs in study. \\
\hline $\begin{array}{l}\text { Free of selective report- } \\
\text { ing? }\end{array}$ & High risk & $\begin{array}{l}\text { No length measurement provided. } \\
\text { No head circumference measurement provided. }\end{array}$ \\
\hline Free of other bias? & Low risk & $\begin{array}{l}\text { Suitable follow-up at 6-weeks post-surgery. } \\
\text { Comparable baseline data. }\end{array}$ \\
\hline
\end{tabular}


Masarei 2007

\begin{tabular}{|c|c|}
\hline Methods & $\begin{array}{l}\text { Single-centre RCT conducted across North Thames Regional Cleft Centre's two sites. } \\
6 \text { month intervention, } 12 \text { month follow-up. } \\
\text { Conducted in UK. }\end{array}$ \\
\hline Participants & $\begin{array}{l}50 \text { babies, } 34 \text { with unilateral cleft lip and palate }(U C L P) \text { and } 16 \text { with isolated cleft palate (ICP). Those re- } \\
\text { quiring cardiac surgery or with neurological impairment and/or syndrome known to adversely affect } \\
\text { feeding were excluded. One baby withdrawn from study due to medical complications. } \\
\text { Gestational age: Gp1, UCLP }=39.75 \text { weeks, ICP }=39.21 \text { weeks. Gp2, UCLP }=39.61 \text { weeks, ICP }=40.29 \\
\text { weeks. } \\
\text { Gender (m/f): GP1 }=16 \text { male, } 9 \text { female, Gp2 }=14 \text { male, } 10 \text { female. } \\
\text { UCLP: } G p 1=17, G p 2=16 \text {. } \\
\text { ICP: } G p 1=8, G p 2=8 .\end{array}$ \\
\hline
\end{tabular}

$\begin{array}{ll}\text { Interventions } & \text { Gp1. Presurgical Orthopedics (PSO) or maxillary plate (presurgical) }(n=25) . \\ \text { Gp2. No PSO (presurgical) }(n=24) \text {. } \\ \text { All Cleft palates were repaired when child was } 6 \text { months old. }\end{array}$

Outcomes Weight $(\mathrm{kg})$ recorded at birth, 3-months and 12-months of age. Height $(\mathrm{cm})$ recorded at 3-months and 12 -months of age. Head circumference $(\mathrm{cm})$ recorded at 3-months and 12-months of age.

Notes Funded Action Research.

\section{Risk of bias}

\begin{tabular}{|c|c|c|}
\hline Bias & Authors' judgement & Support for judgement \\
\hline $\begin{array}{l}\text { Adequate sequence gener- } \\
\text { ation? }\end{array}$ & Low risk & Computer sequence generation using MINIM. \\
\hline Allocation concealment? & Low risk & Allocation handled using automated computer generation. \\
\hline $\begin{array}{l}\text { Blinding? } \\
\text { All outcomes }\end{array}$ & High risk & $\begin{array}{l}\text { Speech and language therapists were blinded for sucking reflexes. } \\
\text { Height and weight measures taken by study researcher. }\end{array}$ \\
\hline $\begin{array}{l}\text { Incomplete outcome data } \\
\text { addressed? } \\
\text { All outcomes }\end{array}$ & Unclear risk & $\begin{array}{l}\text { 3-month data - adequate. } \\
\text { 12-month data contains drop outs not reported. }\end{array}$ \\
\hline $\begin{array}{l}\text { Free of selective report- } \\
\text { ing? }\end{array}$ & Unclear risk & 6-month pre-surgery data not presented. \\
\hline Free of other bias? & Unclear risk & $\begin{array}{l}\text { The maxillary plate group received more visits and checks during study than } \\
\text { control group. } \\
\text { Compliance with using the plate is unclear. }\end{array}$ \\
\hline
\end{tabular}

Prahl 2005

\begin{tabular}{ll} 
Methods & Multicentre RCT. \\
& $\begin{array}{l}18 \text { month follow-up. } \\
\text { Conducted in The Netherlands. }\end{array}$ \\
\hline Participants & $\begin{array}{l}54 \text { babies with complete unilateral cleft lip and palate. Babies born at term. Babies with other congeni- } \\
\text { tal malformations and soft tissue bands were excluded. } \\
\text { Age: randomised within } 2 \text { weeks of birth. }\end{array}$
\end{tabular}


Prahl 2005 (Continued)

Gender: 41 boys, 13 girls.

Interventions Gp1. Passive acrylic plate, worn 24 hour/day. Plates initially adjusted every 3 weeks. Plate maintained until surgical soft palate closure $(n=27)$.

Gp2. No plate worn $(n=27)$.

In both groups lip surgery was performed according to the Millard technique (18 weeks of age); soft palate closure was performed according to a modified Von Lagenbeck procedure ( 52 weeks of age).

Outcomes Weight $(\mathrm{kg})$ and length $(\mathrm{cm})$ and feeding diaries.

Weight-for-age, length-for-age and weight-for-length z-scores were evaluated.

Notes Funded by National Health Insurance Board of The Netherlands.

\section{Risk of bias}

\begin{tabular}{lll}
\hline Bias & Authors' judgement & Support for judgement \\
\hline $\begin{array}{l}\text { Adequate sequence gener- } \\
\text { ation? }\end{array}$ & Low risk & Computer balanced allocation procedure. \\
\hline Allocation concealment? & Low risk & Computer balanced allocation procedure. \\
\hline $\begin{array}{l}\text { Blinding? } \\
\text { All outcomes }\end{array}$ & Low risk & Weight and length measured by the National Infant Consultation Centers. \\
\hline $\begin{array}{l}\text { Incomplete outcome data } \\
\text { addressed? } \\
\text { All outcomes }\end{array}$ & Unclear risk & Reasons for drop outs not reported. \\
\hline $\begin{array}{l}\text { Free of selective report- } \\
\text { ing? }\end{array}$ & High risk & No reporting of head circumference. \\
\hline $\begin{array}{l}\text { Free of other bias? } \\
\text { Low risk }\end{array}$ & & Comparable baseline data. \\
\hline
\end{tabular}

Shaw 1999

$\begin{array}{ll}\text { Methods } & \text { Single-centre RCT. } \\ & 12 \text { month follow-up. } \\ & \text { Conducted in UK. }\end{array}$

\begin{tabular}{ll}
\hline Participants & 101 otherwise healthy babies with clefts \\
& Age: randomised at birth. \\
& Gender $(\mathrm{m} / \mathrm{f}): \mathrm{Gp} 1=27 / 22, \mathrm{Gp} 2=31 / 21$. \\
& Isolated cleft lip: $\mathrm{Gp} 1=10, \mathrm{Gp} 2=15$. \\
& Isolated cleft palate: $\mathrm{Gp} 1=16, \mathrm{Gp} 2=15$. \\
& Cleft lip and palate: $\mathrm{Gp} 1=23, \mathrm{Gp} 2=22$. \\
& South Asian mother: $\mathrm{Gp} 1=4, \mathrm{Gp} 2=12$.
\end{tabular}

Interventions Gp1. Squeezable bottle with Nuk orthodontic teat $(n=49)$.

Gp2. Rigid bottle with Nuk orthodontic teat $(n=52)$.

All mother-infant pairs received individual assessment of infant's oral feeding.

Outcomes

Weight $(\mathrm{kg})$, head circumference $(\mathrm{cm})$ and crown-heel length $(\mathrm{cm})$ were measured by trained researcher at birth, 6, 13, 26 and 52 weeks.

Parental satisfaction was recorded as mothers report of ease/pleasure of feeding. 
Shaw 1999 (Continued)

24 hour log of time taken to feed.

Reliability of feeding methods (number of adjustments necessary).

\begin{tabular}{|c|c|c|}
\hline Notes & Funded by Action Res & rch Grant and North West Regional Health Authority, UK. \\
\hline \multicolumn{3}{|l|}{ Risk of bias } \\
\hline Bias & Authors' judgement & Support for judgement \\
\hline $\begin{array}{l}\text { Adequate sequence gener- } \\
\text { ation? }\end{array}$ & Low risk & Generated by trial statistician. \\
\hline Allocation concealment? & Low risk & Opaque envelopes opened by clinician. \\
\hline $\begin{array}{l}\text { Blinding? } \\
\text { All outcomes }\end{array}$ & High risk & Outcome assessor was trial investigator. \\
\hline $\begin{array}{l}\text { Incomplete outcome data } \\
\text { addressed? } \\
\text { All outcomes }\end{array}$ & Low risk & Drop outs listed and described in full. \\
\hline $\begin{array}{l}\text { Free of selective report- } \\
\text { ing? }\end{array}$ & Low risk & Length, height and head circumference measures listed. \\
\hline Free of other bias? & Low risk & $\begin{array}{l}\text { Comparable baseline data. } \\
\text { Adequate follow-up period. }\end{array}$ \\
\hline
\end{tabular}

FTT - Failure to thrive, defined as weight less than fifth centile NCHS - National Centre for Health Statistics

Characteristics of excluded studies [ordered by study ID]

\begin{tabular}{ll}
\hline Study & Reason for exclusion \\
\hline Bongaarts 2009 & No measures of growth, development or parental satisfaction included. \\
\hline Kim 2009 & Assessed unrestricted bottle feeding following cleft palate repair. \\
& All participants were older than 6 months of age. \\
\hline Lauer 2000 & No measures of growth, development or parental satisfaction included. \\
\hline
\end{tabular}

\section{DATA AND ANALYSES}

\section{Comparison 1. Rigid versus squeezable bottle}

\begin{tabular}{lllll}
\hline Outcome or subgroup title & $\begin{array}{l}\text { No. of } \\
\text { studies }\end{array}$ & $\begin{array}{l}\text { No. of } \\
\text { partici- } \\
\text { pants }\end{array}$ & Statistical method & Effect size \\
\hline 1 Weight $(\mathrm{kg})$ & 2 & & Mean Difference (IV, Fixed, $95 \% \mathrm{Cl})$ & Subtotals only \\
\hline \hline
\end{tabular}




\begin{tabular}{|c|c|c|c|c|}
\hline Outcome or subgroup title & $\begin{array}{l}\text { No. of } \\
\text { studies }\end{array}$ & $\begin{array}{l}\text { No. of } \\
\text { partici- } \\
\text { pants }\end{array}$ & Statistical method & Effect size \\
\hline 1.1 Up to 2 months & 1 & 101 & Mean Difference (IV, Fixed, 95\% Cl) & $-0.05[-0.25,0.15]$ \\
\hline $1.2>2$ months to 6 months & 2 & 131 & Mean Difference (IV, Fixed, 95\% CI) & $-0.10[-0.42,0.23]$ \\
\hline $1.3>6$ months & 2 & 130 & Mean Difference (IV, Fixed, 95\% CI) & $-0.15[-0.53,0.22]$ \\
\hline 2 Length (cm) & 2 & & Mean Difference (IV, Fixed, 95\% CI) & Subtotals only \\
\hline 2.1 Up to 2 months & 1 & 101 & Mean Difference (IV, Fixed, 95\% Cl) & $0.0[-0.84,0.84]$ \\
\hline $2.2>2$ months to 6 months & 2 & 131 & Mean Difference (IV, Fixed, 95\% CI) & $0.20[-0.59,0.98]$ \\
\hline $2.3>6$ months & 2 & 130 & Mean Difference (IV, Fixed, 95\% CI) & $0.21[-0.72,1.14]$ \\
\hline 3 Head circumference $(\mathrm{cm})$ & 2 & & Mean Difference (IV, Fixed, 95\% CI) & Subtotals only \\
\hline 3.1 Up to 2 months & 1 & 101 & Mean Difference (IV, Fixed, 95\% CI) & $-0.40[-0.99,0.19]$ \\
\hline $3.2>2$ months to 6 months & 2 & 131 & Mean Difference (IV, Fixed, 95\% Cl) & $-0.28[-0.70,0.14]$ \\
\hline $3.3>6$ months & 2 & 130 & Mean Difference (IV, Fixed, 95\% CI) & $-0.66[-1.16,-0.17]$ \\
\hline
\end{tabular}

Analysis 1.1. Comparison 1 Rigid versus squeezable bottle, Outcome 1 Weight (kg).

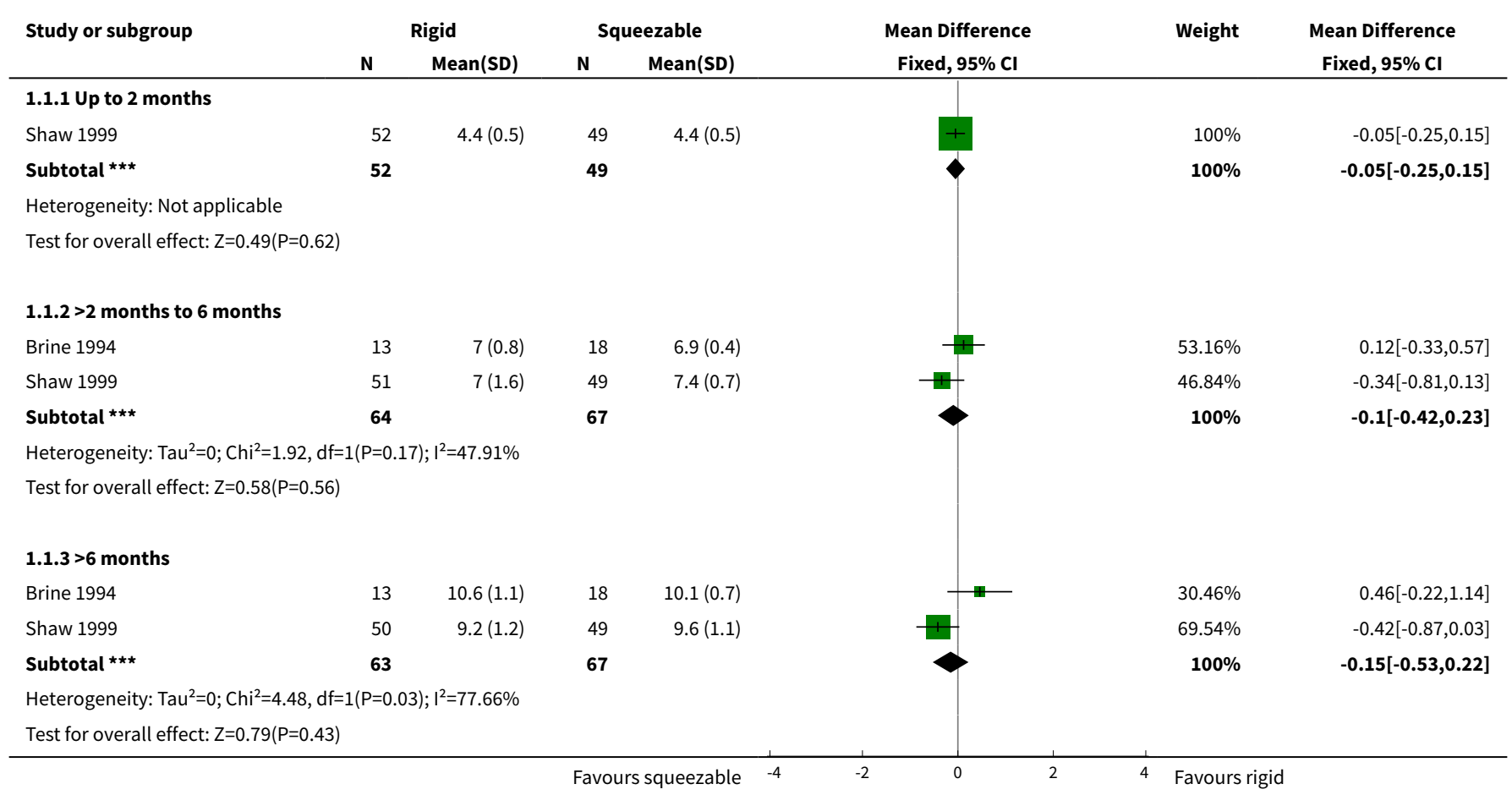


Analysis 1.2. Comparison 1 Rigid versus squeezable bottle, Outcome 2 Length (cm).

\begin{tabular}{|c|c|c|c|c|c|c|c|}
\hline \multirow[t]{2}{*}{ Study or subgroup } & \multicolumn{2}{|c|}{ Rigid } & \multicolumn{2}{|c|}{ Squeezable } & \multirow{2}{*}{$\begin{array}{c}\text { Mean Difference } \\
\text { Fixed, } 95 \% \mathrm{Cl}\end{array}$} & \multirow[t]{2}{*}{ Weight } & \multirow{2}{*}{$\begin{array}{c}\text { Mean Difference } \\
\text { Fixed, } 95 \% \mathrm{Cl}\end{array}$} \\
\hline & $\mathbf{N}$ & Mean(SD) & $\mathbf{N}$ & $\operatorname{Mean}(S D)$ & & & \\
\hline \multicolumn{8}{|l|}{ 1.2.1 Up to 2 months } \\
\hline Shaw 1999 & 52 & $55.3(2)$ & 49 & $55.3(2.3)$ & & $100 \%$ & $0[-0.84,0.84]$ \\
\hline 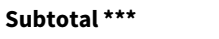 & 52 & & 49 & & & $100 \%$ & $0[-0.84,0.84]$ \\
\hline \multicolumn{8}{|c|}{ Heterogeneity: Not applicable } \\
\hline \multicolumn{8}{|c|}{ Test for overall effect: Not applicable } \\
\hline \multicolumn{8}{|c|}{ 1.2.2 $>2$ months to 6 months } \\
\hline Brine 1994 & 13 & $64.5(1.8)$ & 18 & $63.5(2.5)$ & 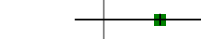 & $26.9 \%$ & $1[-0.51,2.51]$ \\
\hline Shaw 1999 & 51 & $66.7(2.5)$ & 49 & $66.8(2.2)$ & & $73.1 \%$ & $-0.1[-1.02,0.82]$ \\
\hline 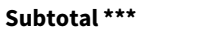 & 64 & & 67 & & & $100 \%$ & $0.2[-0.59,0.98]$ \\
\hline \multicolumn{8}{|c|}{ Heterogeneity: $\operatorname{Tau}^{2}=0 ; \mathrm{Chi}^{2}=1.48, \mathrm{df}=1(\mathrm{P}=0.22) ; \mathrm{I}^{2}=32.56 \%$} \\
\hline \multicolumn{8}{|c|}{ Test for overall effect: $Z=0.49(P=0.62)$} \\
\hline \multicolumn{8}{|l|}{ 1.2.3 >6 months } \\
\hline Brine 1994 & 13 & $80.6(2.9)$ & 18 & $78.7(2.4)$ & & $23.34 \%$ & $1.9[-0.03,3.83]$ \\
\hline Shaw 1999 & 50 & $74.8(3)$ & 49 & $75.1(2.3)$ & & $76.66 \%$ & $-0.3[-1.36,0.76]$ \\
\hline 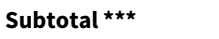 & 63 & & 67 & & & $100 \%$ & $0.21[-0.72,1.14]$ \\
\hline \multicolumn{8}{|c|}{ Heterogeneity: $\operatorname{Tau}^{2}=0 ; \mathrm{Chi}^{2}=3.84, \mathrm{df}=1(\mathrm{P}=0.05) ; \mathrm{I}^{2}=73.94 \%$} \\
\hline Test for overall effect & & & & & & & \\
\hline
\end{tabular}

Analysis 1.3. Comparison 1 Rigid versus squeezable bottle, Outcome 3 Head circumference $(\mathrm{cm})$.

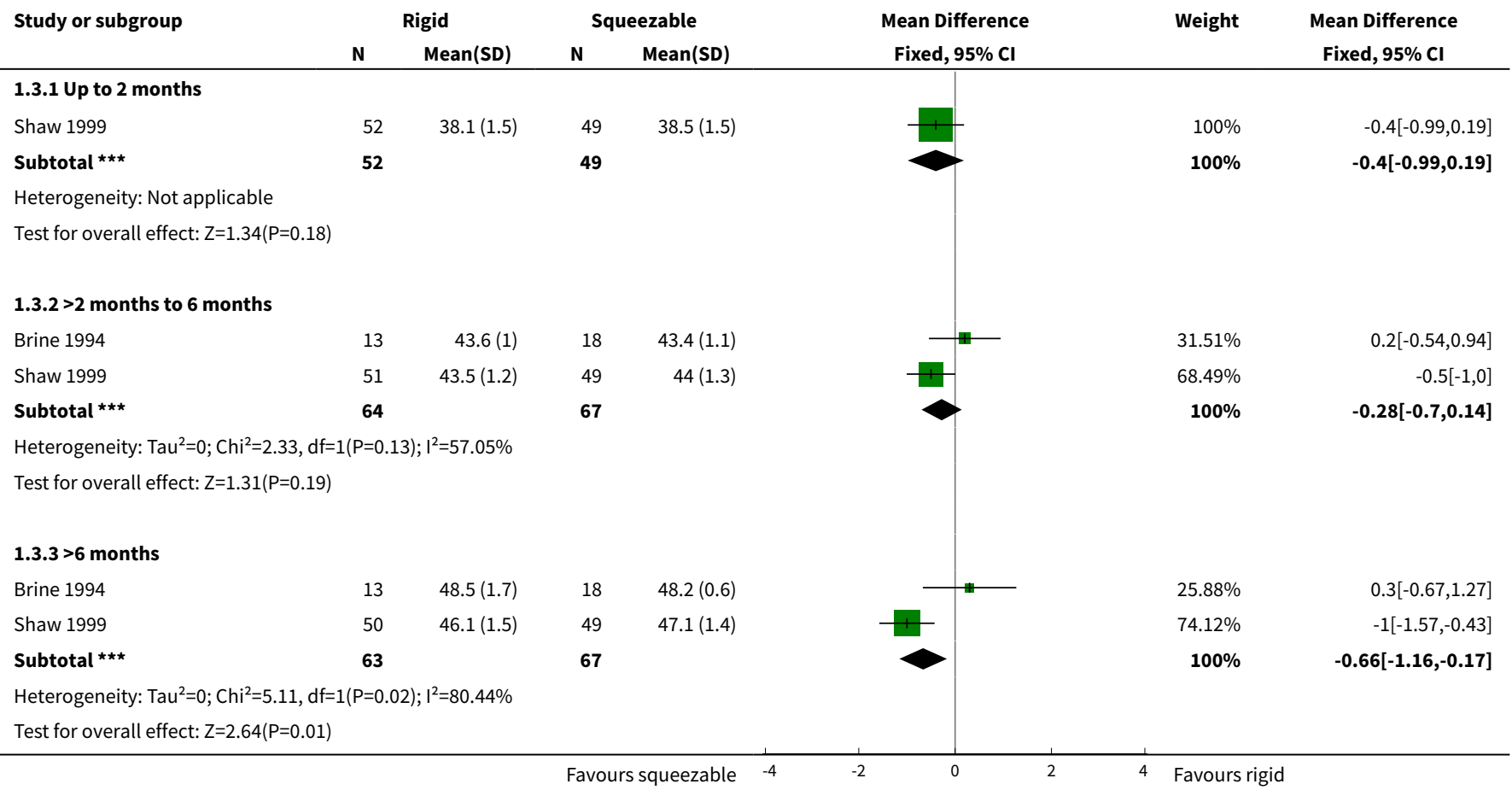


Comparison 2. Breastfeeding versus spoon-feeding

\begin{tabular}{lllll}
\hline Outcome or subgroup title & $\begin{array}{l}\text { No. of } \\
\text { studies }\end{array}$ & $\begin{array}{l}\text { No. of } \\
\text { partici- } \\
\text { pants }\end{array}$ & Statistical method & Effect size \\
\hline 1 Weight $(\mathrm{kg})$ & 1 & Mean Difference (IV, Fixed, $95 \% \mathrm{Cl})$ & Totals not selected \\
\hline $1.1>6$ months & 1 & Mean Difference (IV, Fixed, $95 \% \mathrm{Cl})$ & $0.0[0.0,0.0]$ \\
\hline 2 Duration of hospital stay (days) & 1 & Mean Difference (IV, Fixed, $95 \% \mathrm{Cl})$ & Totals not selected \\
\hline
\end{tabular}

Analysis 2.1. Comparison 2 Breastfeeding versus spoon-feeding, Outcome 1 Weight (kg).

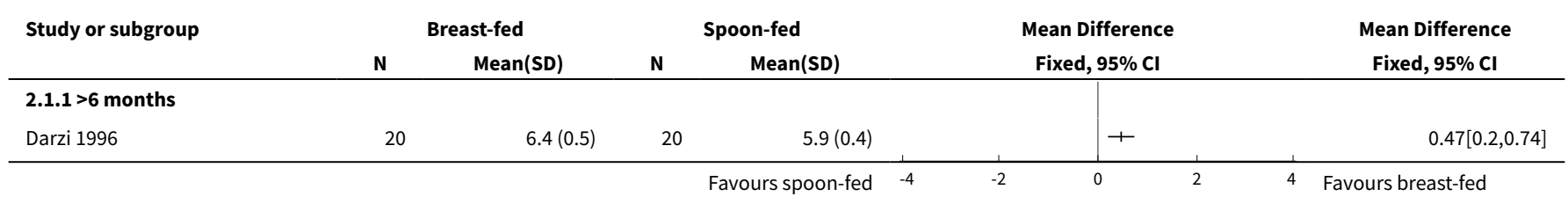

Analysis 2.2. Comparison 2 Breastfeeding versus spoon-feeding, Outcome 2 Duration of hospital stay (days).

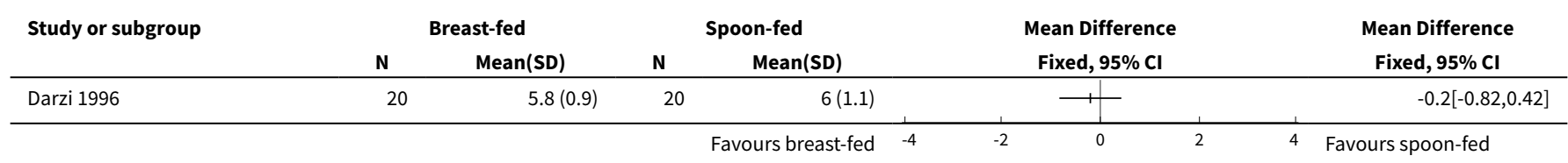

Comparison 3. Maxillary plate versus no plate

\begin{tabular}{llllll}
\hline Outcome or subgroup title & $\begin{array}{l}\text { No. of } \\
\text { studies }\end{array}$ & $\begin{array}{l}\text { No. of } \\
\text { partici- } \\
\text { pants }\end{array}$ & Statistical method & Effect size \\
\hline 1 Weight (kg) & 2 & & Mean Difference (IV, Fixed, 95\% Cl) & Subtotals only \\
\hline 1.12 months (54 to 67 days) & 2 & 72 & Mean Difference (IV, Fixed, 95\% Cl) & $-0.02[-0.35,0.30]$ \\
\hline 1.26 months (176 to 190 days) & 1 & 28 & Mean Difference (IV, Fixed, 95\% Cl) & $-0.57[-1.14,-0.00]$ \\
\hline 1.312 months (351 to 379 days) & 2 & 50 & Mean Difference (IV, Fixed, 95\% Cl) & $0.10[-0.53,0.73]$ \\
\hline 2 Length (cm) & 2 & & Mean Difference (IV, Fixed, 95\% Cl) & Subtotals only \\
\hline 2.1 Up to 2 months & 1 & 17 & Mean Difference (IV, Fixed, 95\% Cl) & $0.24[-1.86,2.34]$ \\
\hline $2.2>2$ months to 6 months & 2 & 74 & Mean Difference (IV, Fixed, 95\% Cl) & $-1.05[-2.20,0.11]$ \\
\hline $2.3>6$ months & 1 & 18 & Mean Difference (IV, Fixed, 95\% Cl) & $-0.78[-3.68,2.12]$ \\
\hline
\end{tabular}




\begin{tabular}{lllll}
\hline Outcome or subgroup title & $\begin{array}{l}\text { No. of } \\
\text { studies }\end{array}$ & $\begin{array}{l}\text { No. of } \\
\text { partici- } \\
\text { pants }\end{array}$ & Statistical method & Effect size \\
\hline $2.4>12$ months & 1 & 31 & Mean Difference (IV, Fixed, 95\% Cl) & $-1.29[-3.86,1.28]$ \\
\hline 3 Head Circumference $(\mathrm{cm})$ & 1 & & Mean Difference (IV, Fixed, 95\% Cl) & Subtotals only \\
\hline 3.13 months & 1 & 46 & Mean Difference (IV, Fixed, 95\% Cl) & $0.30[-0.66,1.26]$ \\
\hline 3.212 months & 1 & 32 & Mean Difference (IV, Fixed, 95\% Cl) & $0.25[-1.03,1.53]$ \\
\hline
\end{tabular}

Analysis 3.1. Comparison 3 Maxillary plate versus no plate, Outcome 1 Weight (kg).

\begin{tabular}{|c|c|c|c|c|c|c|c|}
\hline \multirow[t]{2}{*}{ Study or subgroup } & \multicolumn{2}{|c|}{ Plate } & \multicolumn{2}{|c|}{ No plate } & \multirow{2}{*}{$\begin{array}{c}\text { Mean Difference } \\
\text { Fixed, } 95 \% \mathrm{Cl} \\
\end{array}$} & \multirow[t]{2}{*}{ Weight } & \multirow{2}{*}{$\begin{array}{c}\text { Mean Difference } \\
\text { Fixed, } 95 \% \mathrm{Cl} \\
\end{array}$} \\
\hline & $\mathbf{N}$ & Mean(SD) & $\mathbf{N}$ & Mean(SD) & & & \\
\hline \multicolumn{8}{|c|}{ 3.1.1 2 months (54 to 67 days) } \\
\hline Masarei 2007 & 24 & $5.5(0.7)$ & 23 & $5.5(0.9)$ & 廿 & $48.99 \%$ & $-0.06[-0.52,0.4]$ \\
\hline Prahl 2005 & 13 & $4.7(0.5)$ & 12 & $4.7(0.6)$ & & $51.01 \%$ & $0.01[-0.44,0.46]$ \\
\hline Subtotal $* \star \star$ & 37 & & 35 & & & $100 \%$ & $-0.02[-0.35,0.3]$ \\
\hline \multicolumn{8}{|c|}{ Heterogeneity: $\mathrm{Tau}^{2}=0 ; \mathrm{Chi}^{2}=0.05, \mathrm{df}=1(\mathrm{P}=0.83) ; \mathrm{I}^{2}=0 \%$} \\
\hline \multicolumn{8}{|c|}{ Test for overall effect: $\mathrm{Z}=0.15(\mathrm{P}=0.88)$} \\
\hline \multicolumn{8}{|c|}{ 3.1.2 6 months ( 176 to 190 days) } \\
\hline Prahl 2005 & 15 & $7(0.5)$ & 13 & $7.6(0.9)$ & & $100 \%$ & $-0.57[-1.14,-0]$ \\
\hline 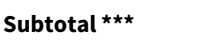 & 15 & & 13 & & & $100 \%$ & $-0.57[-1.14,-0]$ \\
\hline \multicolumn{8}{|c|}{ Heterogeneity: Not applicable } \\
\hline \multicolumn{8}{|c|}{ Test for overall effect: $Z=1.97(P=0.05)$} \\
\hline \multicolumn{8}{|c|}{ 3.1.3 12 months (351 to 379 days) } \\
\hline Masarei 2007 & 20 & $10.1(1.4)$ & 12 & $10.1(1.5)$ & - & $36.81 \%$ & $-0.05[-1.09,0.99]$ \\
\hline Prahl 2005 & 6 & $9.8(0.9)$ & 12 & $9.6(0.7)$ & & $63.19 \%$ & $0.18[-0.61,0.97]$ \\
\hline Subtotal $\star \star \star ~$ & 26 & & 24 & & & $100 \%$ & $0.1[-0.53,0.73]$ \\
\hline \multicolumn{8}{|c|}{ Heterogeneity: $\operatorname{Tau}^{2}=0 ; \mathrm{Chi}^{2}=0.12, \mathrm{df}=1(\mathrm{P}=0.73) ; 1^{2}=0 \%$} \\
\hline Test for overall effect & & & & & & & \\
\hline
\end{tabular}

Analysis 3.2. Comparison 3 Maxillary plate versus no plate, Outcome 2 Length (cm).

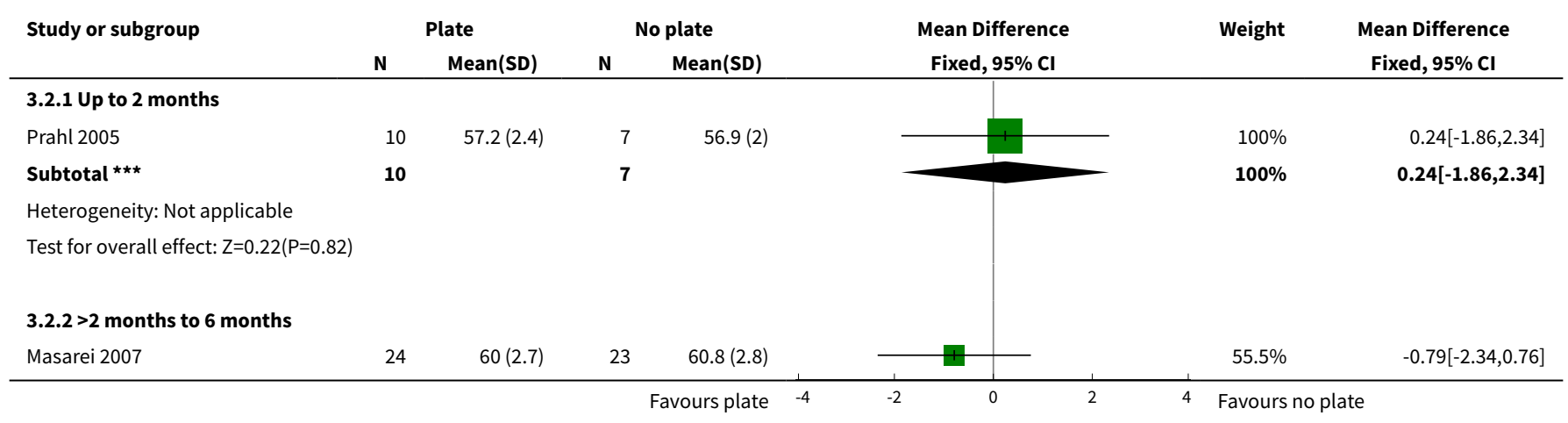




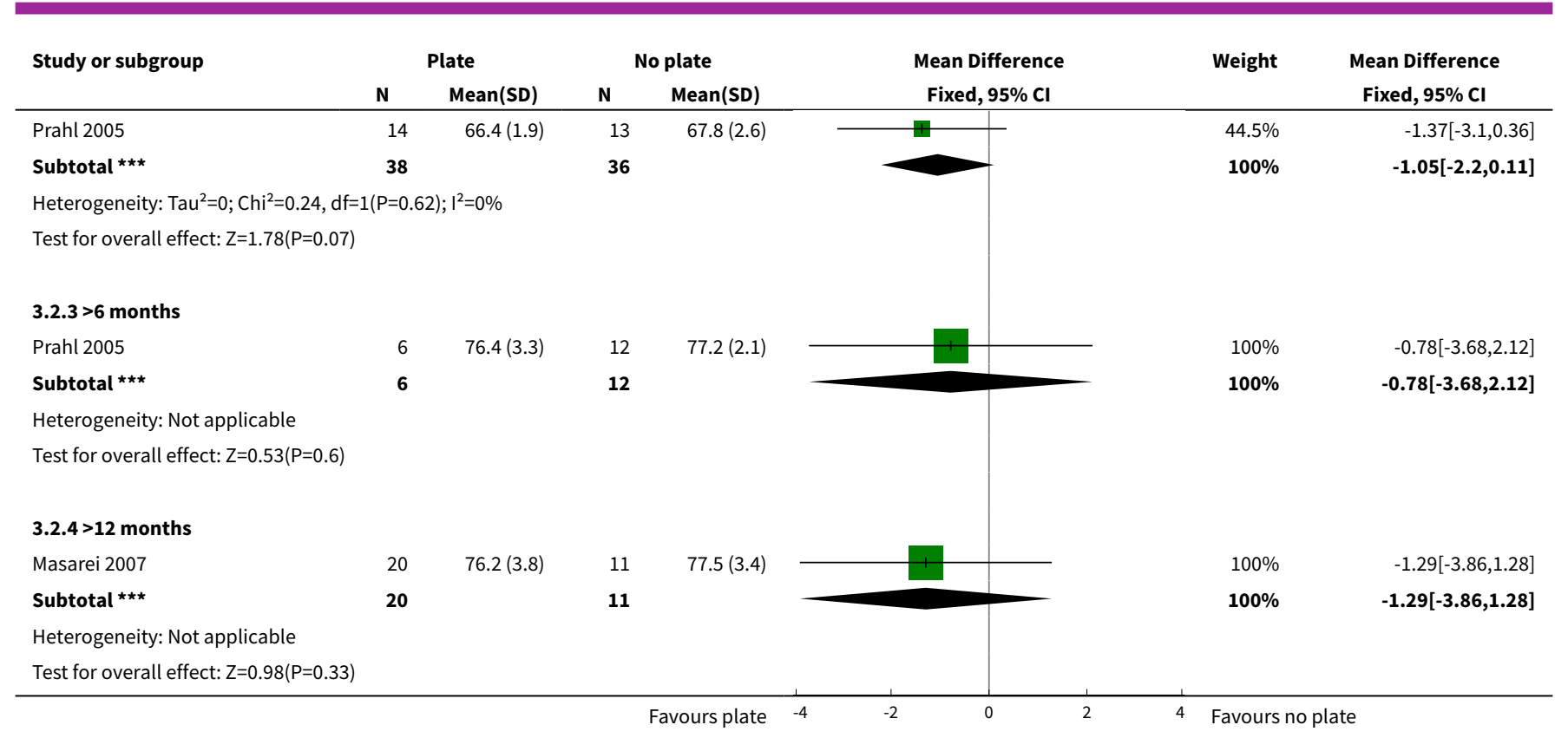

Analysis 3.3. Comparison 3 Maxillary plate versus no plate, Outcome 3 Head Circumference $(\mathrm{cm})$.

\begin{tabular}{|c|c|c|c|c|c|c|c|}
\hline \multirow[t]{2}{*}{ Study or subgroup } & \multicolumn{2}{|c|}{ Plate } & \multicolumn{2}{|c|}{ No plate } & \multirow{2}{*}{$\begin{array}{c}\text { Mean Difference } \\
\text { Fixed, } 95 \% \mathrm{CI}\end{array}$} & \multirow[t]{2}{*}{ Weight } & \multirow{2}{*}{$\begin{array}{c}\text { Mean Difference } \\
\text { Fixed, } 95 \% \mathrm{Cl}\end{array}$} \\
\hline & $\mathbf{N}$ & Mean(SD) & $\mathbf{N}$ & $\operatorname{Mean}(S D)$ & & & \\
\hline \multicolumn{8}{|l|}{ 3.3.1 3 months } \\
\hline Masarei 2007 & 23 & $40.3(1.8)$ & 23 & $40(1.5)$ & & $100 \%$ & $0.3[-0.66,1.26]$ \\
\hline 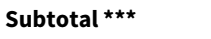 & 23 & & 23 & & & $100 \%$ & $0.3[-0.66,1.26]$ \\
\hline \multicolumn{8}{|c|}{ Heterogeneity: Not applicable } \\
\hline \multicolumn{8}{|c|}{ Test for overall effect: $Z=0.61(P=0.54)$} \\
\hline \multicolumn{8}{|l|}{ 3.3.2 12 months } \\
\hline Masarei 2007 & 20 & $46.6(1.7)$ & 12 & $46.3(1.9)$ & + & $100 \%$ & $0.25[-1.03,1.53]$ \\
\hline Subtotal ${ }^{\star \star \star}$ & 20 & & 12 & & 1 & $100 \%$ & $0.25[-1.03,1.53]$ \\
\hline \multicolumn{8}{|c|}{ Heterogeneity: Not applicable } \\
\hline \multicolumn{8}{|c|}{ Test for overall effect: $Z=0.38(P=0.7)$} \\
\hline \multicolumn{8}{|c|}{ Test for subgroup differences: $\mathrm{Chi}^{2}=0, \mathrm{df}=1(\mathrm{P}=0.95), \mathrm{I}^{2}=0 \%$} \\
\hline
\end{tabular}

\section{APPENDICES}

\section{Appendix 1. MEDLINE (OVID) search strategy}

1. Mouth abnormalities/

2. Cleft lip/

3. Cleft palate/

4. (cleft adj5 (lip\$ or palat\$ or oral or orofacial)).mp.

5. (harelip\$ or hare-lip\$).mp.

6. or/1-5

7. exp Infant nutritional physiological phenomena/

8. Feeding behavior/

Feeding interventions for growth and development in infants with cleft lip, cleft palate or cleft lip and palate (Review) 
9. Feeding methods/

10.("breast fe?d\$" or breast-fe?d\$ or breastfe?d\$).mp.

11.("bottle fe?d\$" or bottle-fe?d\$ or bottlefe?d\$).mp.

12.(fe?d adj5 (bottle\$ or breast)).mp.

13.teat\$.mp.

14.(plate\$ adj5 obturat\$).mp.

15.("feeding plate\$" or feeding-plate\$).mp.

$16.0 \mathrm{r} / 7-15$

17.6 and 16

\section{Appendix 2. Cochrane Oral Health Group Trials Register Search Strategy}

((cleft* or hare-lip* or harelip $\left.{ }^{\star}\right)$ and (nutrition* or feed ${ }^{\star}$ or fed or bottle* or breast or teat ${ }^{\star}$ or "feeding plate*" or feeding-plate*))

\section{Appendix 3. Cochrane Register of Controlled Clinical Trials (CENTRAL) Search Strategy}

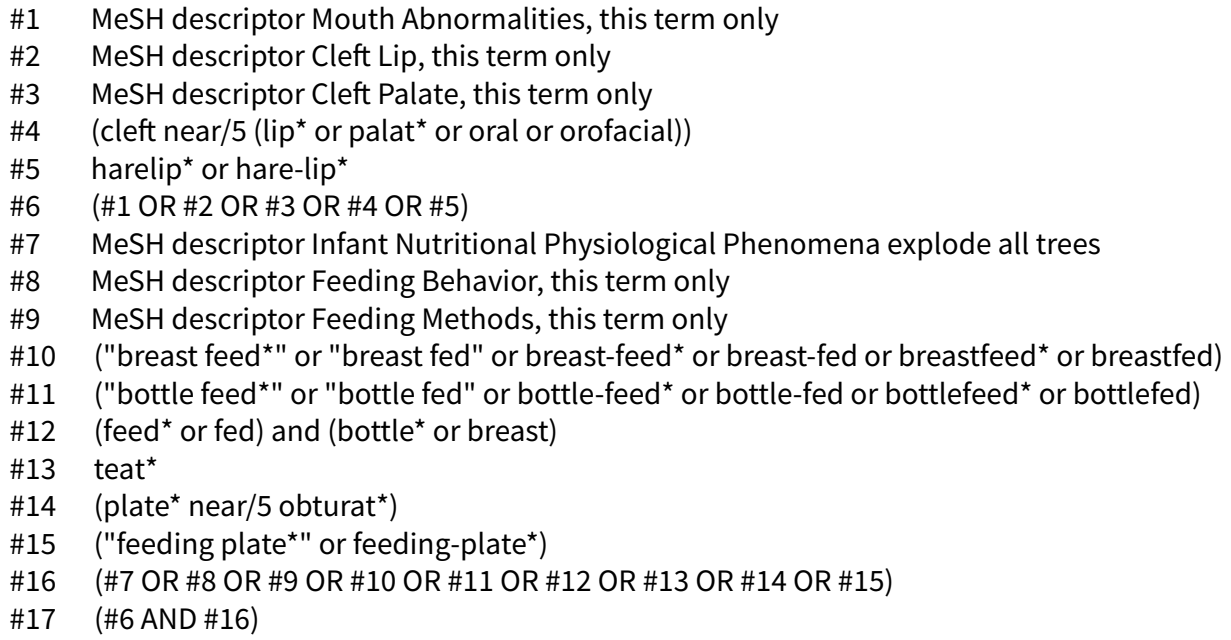

\section{Appendix 4. EMBASE (OVID) Search Strategy}

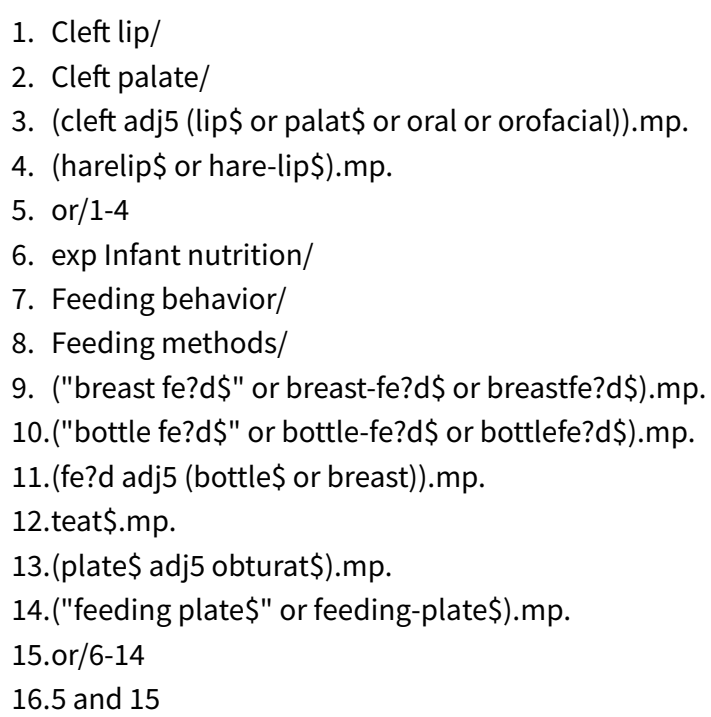

\section{Appendix 5. PsycINFO (OVID) Search Strategy}

1. exp Cleft Palate/

2. (cleft and (lip\$ or palate\$ or oral or orofacial)).mp.

3. (harelip\$ or hare-lip\$).mp.

4. or/1-3

5. exp Eating behavior/

Feeding interventions for growth and development in infants with cleft lip, cleft palate or cleft lip and palate (Review) 
6. $\exp$ Nutrition/

7. ("breast fe?d\$" or breast-fe?d\$ or breastfe?d\$).mp.

8. ("bottle fe?d\$" or bottle-fe?d\$ or bottlefe?d\$).mp.

9. (fe?d adj5 (bottle\$ or breast)).mp.

10. teat\$.mp.

11. (plate\$ adj5 obturat\$).mp.

12. ("feeding plate\$" or feeding-plate\$).mp.

13. or $/ 5-12$

14. 4 and 13

\section{Appendix 6. CINAHL (EBSCO) Search Strategy}

S1 MH "Mouth Abnormalities"

S2 MH "Cleft Lip"

S3 MH "Cleft Palate"

S4 cleft N5 lip* or cleft N5 palat* or cleft N5 oral or cleft N5 orofacial

S5 harelip* or hare-lip*

$\mathrm{S} 6 \mathrm{~S} 1$ or $\mathrm{S} 2$ or $\mathrm{S} 3$ or $\mathrm{S} 4$ or S5

S7 MH "Infant Nutrition+"

S8 $\mathrm{MH}$ "Eating Behavior"

S9 $\mathrm{MH}$ "Infant Feeding+"

S10 "breast fe?d" or breast-fe?d or breastfe?d

S11 "bottle fe?d" or bottle-fe?d or bottlefe?d

S12 fe?d N5 bottle* or fe?d N5 breast

S13 plate $^{\star}$ N5 obturat ${ }^{\star}$

S14 "feeding plate*" or feeding-plate*

S15 teat*

$\mathrm{S} 16 \mathrm{~S} 7$ or $\mathrm{S} 8$ or $\mathrm{S} 9$ or $\mathrm{S} 10$ or $\mathrm{S} 11$ or $\mathrm{S} 12$ or $\mathrm{S} 13$ or $\mathrm{S} 14$ or $\mathrm{S} 15$

S17 S6 and S16

WHAT' S NEW

\begin{tabular}{lll}
\hline Date & Event & Description \\
\hline 19 January 2011 & $\begin{array}{l}\text { New citation required but conclusions } \\
\text { have not changed }\end{array}$ & Change of authorship. \\
\hline 19 January 2011 & New search has been performed & $\begin{array}{l}\text { Searches updated: one additional included study. Methods } \\
\text { updated: all included studies assessed using latest Cochrane } \\
\text { methodology for assessment of risk of bias. }\end{array}$ \\
\hline
\end{tabular}

\section{H I S T O R Y}

Protocol first published: Issue 4, 2001

Review first published: Issue 3, 2004

\begin{tabular}{lll}
\hline Date & Event & Description \\
\hline 12 August 2008 & New search has been performed & $\begin{array}{l}\text { Converted to new review format. Updated based on new search- } \\
\text { es - January } 2010\end{array}$ \\
\hline
\end{tabular}

\section{CONTRIBUTIONS OF AUTHORS}

Alyson Bessell (AB) and Anne-Marie Glenny (AMG) were responsible for producing the update of this review. $A B$, $A M G$ and members of the Cochrane Oral Health Group editorial team participated in the screening of the identified titles/abstracts. AB and AMG participated in the data extraction and quality assessment of the included trials. $A B$ was responsible for co-ordinating the results of the data extraction and 
quality assessment, inputting data into RevMan and producing the first draft of the review update (excluding the conclusions). All review authors provided comments on the text of the review and were asked to provide their individual implications for practice and further research. $A B$ coordinated the responses to referees comments.

\section{DECLARATIONS OF INTEREST}

None known.

\section{SOURCES OF SUPPORT}

\section{Internal sources}

- University Dental Hospital of Manchester, UK.

\section{External sources}

- No sources of support supplied

\section{DIFFERENCES BETWEEN PROTOCOLANDREVIEW}

The original risk of bias assessment was updated to reflect the new guidelines issued by the Cochrane collaboration on risk of bias assessment (Higgins 2009).

\section{IN DEX TERMS}

\section{Medical Subject Headings (MeSH)}

${ }^{*}$ Cleft Lip; *Cleft Palate; *Feeding Methods [instrumentation]; *Growth; Breast Feeding; Consumer Behavior; Maxillofacial Prosthesis; Parents; Randomized Controlled Trials as Topic

\section{MeSH check words}

Humans; Infant; Infant, Newborn 